\title{
尿中酸フオスフアターゼの测定による 前立腺分泌液の研究
}

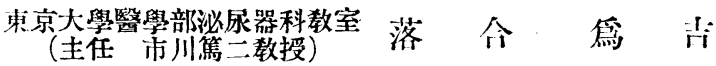

\section{STUDY ON PROSTATIC SECRETION BY MEANS OF THE MEASUREMENT OF ACID PHOSPHATASE IN THE URINE \\ Tamekichi Ochiai \\ From the Urology Department, Medical Faculty, University of Tokyo}

(Director: Prof. Dr. T. Ichikawa)

\section{I. 緒 言}

前立腺分泌液の分泌狀態を究明しようとする時 にあなり我々の得られる分泌液は前立腺マツサー ジによるほかなく，自然の分泌のまるに得られる ちのは尿, 或は精液と混合狀態にあるので, 前立 腺分泌液そのものの分泌狀態を知ることは困難な 現狀にある。

然るに先人の䂰究並びに私の實驗によつて，

1. 前立腺分泌液の酸フオスフアターゼ含倠量 は恒常的であること。

2. 尿中酸フオスフアターゼの大部分の起源は 前立腺分泌液に由來すること。

ぶ明碓になつたので，私は尿中酸フォスフアター ゼを测定することにより今迄明かになつていない 前立腺分泌液そのものの分泌狀態を窥知し，陪床 ト役立をせようとした.

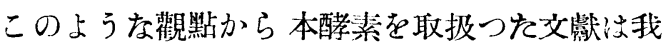
國に於ては未だその發表なく，外國に於てもScott \& Huggins 及び Clark 以外にはないようで，之 等の文獻は戰時中及び最近のものであるため，私 ふ记等に接し得ることがうれ私の研究開始後始 わて發見した次第である。從つて㕌っ偶然にも同 一事項を同一理念の下に研究したが，?の成縝治 必すしも，完全に一致したものばかりではなかつ t.

\section{II. フォスフアターゼの研究歷史}

フォスファターゼとは $\operatorname{Euler}^{1)}(1911)$ が命名した有機
燐文分解す万酵素であって，これが生物界に存在するこ とが知られケ:っは，植物!に於て Zaleski2) (1906), 動物 に於て Harden-Young ${ }^{3}$ (1910) 及び Neuberg ${ }^{4)}(1910)$, 人體に於て Embden ${ }^{5}$ (1915)によってである，この後多 (つ)基礎的䂰究がある. 即ち $\mathrm{Nemec}^{6}$ (1919) は植物種子 にグリセロフォスフアターゼの存在することを發見し， なおこの分解反㫿系の酸度がこの醭素つ作用速度に變化 を與えろことは Kjeldahl によつて知られ Sörensen に ・よつて詳細に研究された。. 又 Glosser-Hussler7)(1912)は 動物及び人屍つ各藏器中のグリセロフオスファターゼの 含有量を比較し，後 Forrai i) (1923)はこ北を更に追試寸 ろとともにアミロイド腎では健康腎より少く，子瘤患者 の筋では健康筋より大であること，間葉から發生した㵴 器は含有しないが癌腫の轉移が起ると含有するに至るこ と等を明かにと，义サッカロフオスフアターゼ，フルク トフオスフアダーゼ及びグリセロフオスフアターゼ等は 皆異つた獨特の酻素であ万ことを明かにこた，又Robinson-Soames ${ }^{9}$ (1924)及び Robinson-Kay'0) (1924) は茼, 骨，軟骨のフォスファターゼに就いて研究した。

Cemuth $^{11)}(1925)$ は佝僂病やテタ $=$ の燐代謝の異常 がフォスフアターゼつ異常に基くのではないかという考 えから乳兒つ藏器, 體液について研究しへクッーゼシフ オスファターゼが肝, 脾, 筋, 督, 膵, 神經及び唾液, 膽汁, 乳汁, 尿, 腧等髓液, 血清に存在することを明か にした，その際彼以前つ學者により等閑に附されていた $\mathrm{pH}$ に大きな意義を見出し藏器及び體波の各フォスファ ターゼの至適 $\mathrm{pH}$ を確定した:とは特筆すべきことであ 万. Forrai8 ${ }^{8}$ (1923), Takahashi' ${ }^{12}$ (1924), Tomita $^{13)}$ (1922) 等がークッーゼジフォスフアターゼについて行つけ賽驗 
成績は皆一致してフォスフアターゼの强度を腎, 脾, 䐙 神經, 朋, 筋つ順とし筋が最小であるとしているが： れは皆 $\mathrm{pH}$ 5〜6で實驗しているからで，各フォスファ ターゼは夫タ至適 $\mathrm{pH}$ を異にしていらからこのような順 序をつける:とは全く適切でないことをDemuth は明 示さた，體液!こついての研究で彼は, 腅膜炎患者つ腦春 髓液中のフォスフアターゼが健康者の10倍であること， 佝僂病及びテタ $=$ の血清つフォスファターゼが $\mathrm{pH}$ 7.4以下及び8.1以上では正常者と一致寸万か $\mathrm{pH} 7.5$ 8.0の間では $\mathrm{pH} 7.5$ より狄第にその强度を增し 7.9 で 最高に達し正常者の 7 倍になり更にアルカリ側では急に 下降寸っこをと明かにこした。尿は $\mathrm{pH} 5$ で可成分解し乳 兒の尿と成人の尿とは大差なく佝僂病患者の尿と健康小 兒の尿とは大差ないと述べている. 又 Demuth はホル モン及び種々の監類つフォスフアターゼ!に及ぼす影響に ついて研究こ，ホルモンは試驗管內ではークッーゼジフ オスファターゼには何の影響も與えないことを明かにに ホ。師ち Insulin, Suprarenin, Cholinchlorid, Pituglandol, Thymoglandol は勿論，何僂病やテタ $=ー に$ 關係あ ろホルモンも皆フオスフアターゼに對しては直接何等の 影響もなかったと述べている. 又監類の影響としては陽 イオン中 $\mathrm{Na}, \mathrm{K}, \mathrm{NH}_{4}$ は何等影翠なく, $\mathrm{Mg}, \mathrm{Ca}$ は至適 $\mathrm{pH}$ 酸性側へ移動させるといい，陰てオンは至適 $\mathrm{pH}$ 移動ささろことはないが燐酸監, 硫酸監, 硝酸監, 沃化物 はフオスファターゼの作用を阻止し，构啸酸鹽，醋酸鹽，

監酸監は何等影響を與えないと述へてている。 Demuthに

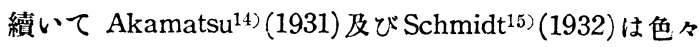
の藏器のフォスフアターゼ溶液がアルカリ領域で第11 至適pHを示寸任かに酸性領域に於て第 2 の至適pHを示 すことを明かにとたが, Bamann ${ }^{16)}(1934)$ はこの二つの 至適pHの存在は必ずにも二つの異つた觸媒を必要とこな いのであつて， :れは隨伴物質の影響と紱衝體つ混合の 特殊作用によるものであることを明かにとた。 Bamann はpH3〜11の範圍でフォスフアターゼ溶液つ作用を檢查 すると共に，フォスファターゼの作用に對する種々の紱 衝體混合つ影響を試驗とた。一方 Erdtman ${ }^{16)}(1928)$ は $\mathrm{Mg}$ イオンがアルカリフォスフアターゼの特別の賦活素 であることを發見したが, Bamannもまたこれを磪認と これによつて至適 $\mathrm{pH}$ の移動は起らないこと及び酸フォ スファターゼは賦活されないことを明かにした。

このよらにしてフオスファターゼつ性狀は次第に明か になりその研究も廣範多岐に互って行われてきたか。 Demuthによつて初めてその存在を指摘された尿中フォ
スファターゼに關する研究も次第に進んできた。 Wald schmidt-Leitz-Nonnenbuch ${ }^{17)}$ (1935) は尿中!は專酸 フォスフアターゼのみが存在ししかもこのものは血液 中には更に多量に存在していると述べている，彼等によ ればフォスフアターゼは血液中で赤血球の中に含まれて いて，血清中にはアルカリフオスフフターゼが僅か!含 まれているつみであつて, Bamann 等が蔽器抽出物中!: 存在すると述べけ酸フォスフアターゼは，賽はえの藏器 に關係する赤血球に由來するのであり，本來の藏器フオ スフアターゼはアルカリフオスフアターゼなのであると こている: こして酸フオスフアターゼが尿中に現われる のは赤血球の成分が崩壤して尿中に出ろからであると主 張した。，一方 Dmochowski-Assenhajm $\left.{ }^{18}\right)(1935)$ は尿中 に至適 $\mathrm{pH} 5.4 \sim 5.6$ の゙リセロフォスフアターゼを見出 こた： :れは本均尿 1 ccで10\%〜20\%グリ七口燐酸監 1 cc $37^{\circ} \mathrm{C} 1$ 時間に分解して $0.1 \sim 0.2 \mathrm{mg}$ の燐を遊踓する ものであつて〔䢴ち $1 \mathrm{cc}$ 尿中 $1 \sim 2$ PE (PhorphataseEinheit) 了强(稀釋するか透析するとその作用は $2 \sim 3$ 倍に上昇すると远べている.人によつては本均值の10倍， 强稀釋又は透析尿で 100 倍もの尿中フォスフアタ一ゼを 有し，最上のフォスフアターゼ標本は，フォスフアター ゼの豊富な尿を透析してアセトン又はアルコールを滴下 す万時得られ，150PEであるとしている。彼等によれば $\mathrm{KCN}, \mathrm{Cu}$ イオン, $\mathrm{NaF}$ は尿フォスフアターゼを强く阻 止 $己$ Cystein は弱く阻止し Phlorrhizin は非常!弱く 阻止すろそこてグリ七口燐酸監の至適濃度は約 $8 \%$ あるとしている. 又稀釋しけ透析血清及び非透析血漿中 に,アルカリフォスフアターゼのほかに冴い酸フォスフ アターゼを發見した，彼等は尿フオスフアターゼと赤血 球フオスフアターゼとを同一視してはならないとと，て の理由として，1．赤血球フオスフアターゼは强い親和 力恒數を有していること．2. 赭球フォスフアターゼ は $\mathrm{Mg}$ 監で賦活されること．3．尿フオスフアターゼは 餘りにも强い增減があって崩壤赤血球に由來していると は考えられない:と等をあげていろ：そこて彼等は尿つ オスフアターゼは腎組糡から由來していて，酸化〜還元 酵素と協同作用をなし糖が腎細管の中へ逆吸收されるよ うに働いているのであると主張てた。

Kutscher-Wörner 及び Wolbergs ${ }^{19) 20) 21) 22) 23)}$ (1935〜 1936)は尿フォスフアターゼについて詳細な砶究をなと その起源の大部分が前立腺であることを確定した。その 大要は炏の如くであろ. 彼等はフメニール䗲酸及び $\beta$ が y七燐酸を分解寸万尿の $\mathrm{pH}$ 作用曲線を求め, 至適 $\mathrm{pH}$ 
が 4 〜 5であることをつきとめ，又酵素を精製するため

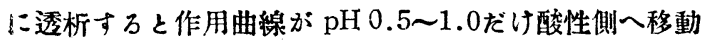
するこ上を知うた，又尿フオスファターゼは Mgイオン により賦活されない，そして尿中にはアルカリフォスフ アターゼがあって血漿フオスフアターゼと比校できる位 の分解能力を有していることを明かにした，尿フオスフ アターセは 5〜6 日間透析しても活動性に變化なく、ト ルオール層下!保存すれば，6週間後も活動性は不變で おろが，高温!は不安定で $60^{\circ} \mathrm{C} て ゙$ 完全に活動性がなく なると述べている。

彼等は尿フォスフアターゼと赤血球フォスフアターゼ とを比较し，赤血球フォスフアターゼは $\beta$-グリを口燐酸 メステルよりa-エステルの方を强く分解寸るが，尿フオ スフアターゼは $\boldsymbol{\alpha}$ エステルより $\boldsymbol{\beta}$ エステテルをよ强く分 解寸ること，义赤血球フォスファターゼは $\mathrm{Mg}$ イオンに より賦活されるが尿フォスフアターゼは賦活されない: と赤血球フオスファターゼの至適 $\mathrm{pH}$ は5.8〜6.5である が尿フォスフアターゼのそれは 4 〜 5であること等を指 摘している.

Wolbergs は尿フオスファターゼの由來に觸れないで 正常の尿フオスフアターゼの排出の狀態を研究した，彼 は先ずフオスフアターゼ排出と尿の比重とは無關係な： とを明かにした。彼の研究の大要は次の如くであろ.17 日間同一榮養條件の下によいけ 5 人（4人は20〜30歳,

1 人は50歲)につき同日時に同一試驗をなし，26っ日間 曲線(男19，女 7 ) 得， 19 (男13，女6)に於て朝に最高 立示し，少义，正午にフォスフアターゼの排出增加を見 ホ. 女子す平均排出量注男子の $1 / 3 \sim 1 / 5$ であつた。在 てこの上昇は食慨時間の前に慨に始まるので食慨性と見 ろつは確かでないが, 次の饑餓試驗を參照するとき, 朝 食が退れて作用している可能性はある。饑解試驗では24 〜36時間食飭攝取を禁止し，水分は排泄しただけ攝取さ せた.するとフォスフアターゼの一般排出水準が本常時

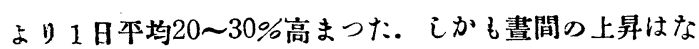
く，1日中排出が一定している，そ:で彼は崖水化物代 謝とつ關係を求めて, Glucose, Insulin, 及び Glucose+ Insulin貸荷によるフォスフアターゼの排出を吥究した。 師古試驗前 $6 \sim 8$ 時間何も食せしめないで $1 \frac{1}{2} 2$ 〜 2 時間 間隔!:探尿，150〜206gの Glucose 等量の水と共!:投

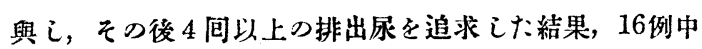
12例!血糖上昇しフォスフアターゼは著明に下降してい ホ. Glucose の頨荷の晹合と同樣にして Insulin 10單位 を注射した結果，10例中 7 例にフォスフアターゼ排出は

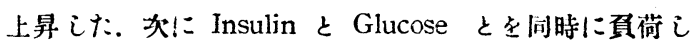
血糖を一定に保つと, Insulin つ作用が優越しフォスフ アターゼ排出量は上昇した。

以上のような榮養との關係を以つてしては不可解であ ろところの早朝及び時に畫食後に現われる短時間繼續す る尿中フォスファターゼ排出の上昇を彼は觀察した。 かもこの上昇は女子や老人では缺如こていらとこらから 彼は男性生殖器の何處からかのフォスフアターゼが混入 すろたのではないかといら想像を抱いけ，そこで射精液 について檢查したところ，その活性は非常に大で，至適 $\mathrm{pH}$ は尿フオスファターゼと全く一致するフォスフアタ 一ゼの存在を知つた。射精液にはフォスフアターゼの含 有量が非常に大であるため僅少の混入でもフォスフアタ 一ゼの排出を說明するミとができた。

猚に生殖器中のどの腺が射精液中のフォスフアターゼ に關係していらのかを確定するため, 個々の藏器につい て憸查した結果，それが前立腺であることが明かになつ ホ..臫ち46歳男子の屍の生殖器系から各臟器を清潔に取

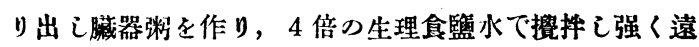
心し沈湘させ上清を滤過し，滤液つ $2 \mathrm{cc}$ 々って醭素添 加とこて實驗したところ, 前立腺抽出液では非常に强力 に分解し，1/100 稀釋を以つてして孔份その作用が認めら れた，前立腺以外の腺は僅かなフォスフアターダこか存 在しないつに前立腺は組織 $1 \mathrm{~g}$ に就き $1200 \mathrm{PE}$ を含有し ていろ，機能大なる射精液は 1 g當り $5580 \mathrm{PE}$ を含有し 全體として 34000 P.Eを生產しているわけであろ. それ 故前立腺は動物體内で最もフォスフアターゼに富んだ臟 器である，彼によれ代腎は $1 \mathrm{~kg}$ 常り14 PE のフォスフ アターゼを含有しているに過ざないのである．えてて活 性 $\mathrm{pH}$ 曲線が完全!二一致することから，射精液中のフォ スフアターゼと前立腺フォスフアターゼとは同一物であ ろことを確定した，偷アルカリフォスフアターゼは前立 腺には少量しか含まれていないと述へててい。

Scott-Huggins ${ }^{24)}$ (1942) の研究により尿フオスフアタ 一ゼの硎究は著しい進展を見ることとなつた，彼等は男 子，女、尒及び子供の尿の酸フォスフアターゼの正常值， 尿中フォスファターゼの起源の昜所，及び去勢狀態が尿 中フォスファターゼ分泌に及ぼす影響を究明すろため King-Armstrong25)(1934) の方法を用い，125 人にっき 2300间の測定を行つた．之等の對象の年齢は生後 2 日か

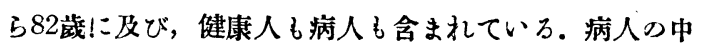
には若い去勢者 1 , 類宦官症 2 , 前立腺㾇で去勢術を受 けた者25がある。そこて檢尿材料は 1. 隨時排尿材料 4 
性交前後の材料，3. 利尿後つ材料，4. 時間每刀材料 5. 尿管尿，6. 24時間中の全尿及び 2 杯分尿試驗（最 初の $30 \mathrm{cc}$ との後のとに分けた)とに區別して蒐集した 尿中のアルカリフォスフアターゼは痕跡程度にこか見出 されないので, 専ら酸フォスアアターゼ!就いて測定し た.

正常人から隨時探尿した材料についてのフォスフアタ 一ゼの活性は，男子は常に同年齢の女子ょり大で，70蔵 以上13歳以下では男女共大差なくて小である。

2 杯試驗に於いては, 正常成人男子は第 1 杯が第 2 杯 より價が高く，女子，少年，老人男子ではいずれも第1 杯と第 2 杯とに差異はない。

1 人に五つの签器に次々と排尿させて憸したところ。 酸フオスファターゼの最大活性は最初の $30 \mathrm{cc}$ 中!含まれ ている.

5 人について射精直後排尿させて檢しケところ, 著明 な酵素の增加が見られた。，然し最初の $30 \mathrm{cc} か ゙$ 通過した後 は平常價に復した。このことは性交の際精液が膀胱內一 逆流こないものであることを，示唆こていると彼等は述 べていろ.

彼等は又10人について尿管尿19材料を取り酵素つ活性 を測定しホが，1例の例外を除いて皆低く，男子の隨時 排泄尿よりも遥か!低く，女子の價よりも稍て低い䨘で あつた：この10人中 7 人においてカテーテルで膀腅尿を 琛取したが，その酸フォスフアターゼの價は尿管尿つ貲 と一致した。殘りの 3 人では膀胱尿!高い䨘が見られた が，これはカテーテル㨉入時前立腺分泌液を䏽胱內一押 と込んだためであろらと述べている。

前立腺の早期㿋で會陰式前立腺全剔除術をなした 64 瓷 男子の術前術後の尿中酸フオスファターゼの測定を行つ たところ, 術後は術前の $1 / 8$ 位に降下し, 術後 4 カ月で は $1 / 16$ 位に降下こた。

隨時排出尿によおいては，1日中での時間!こょる相違や 羁取した飲食物!こより可成の誤差が生ずるので，1日中 の全排出尿について酸フオスフアターゼの量を考えた方 が寧ら標準がきられるという考えから，7人の健康者 について1カ月乃至それ以上の期間，1 日中の尿全體! ついて檢查さた，卡の結果男子では女子の約 4 倍であつ た. 成人男子の酸フォスファター一゙排出量注本均?4時間 に 613 單位で成人女子つは本均163單位であった（1單 位は $37.5^{\circ} \mathrm{C} 30$ 分間にフェニール燐酸りーダを分解して $1 \mathrm{mg}$ のフェノールを遊離させろフォスファターゼ量で あつて尿100ccにこつてであり King-Armstrong 單位で
あろ.) 8 歳の少年の平均值は 48 單位で 8 蔵の少女のは 74 單位であつたと述べている。䦻も彼等はこのフォスフ アターゼの日日の排出量には何等週期を示唆するものが なかったと述べている。

前立腺癌が進行して雨側除睪術をなした 5 人にっいて 尿中酸フオスフアターゼつ排出量を術前 6 日間, 術後 1 〜 2 カ月間測定した：この中 2 人は去勢前尿中酵素は高 濃度を示己尿 100cc中 35〜 i0單位, 24時間排出量 250 400 單位であつたか，兩側除睪術後は 3 迼間の後に著し い减少を示i 100cc中 10 15單位，24時間排出量 100 110 單位でおって，女子においての排出量と同程度であ 万. 殘りの 3 人の中 2 人は術前比挍的低い價であったが 術後の低下がなかった。第 3 番目のものの尿中フォスフ アターゼは, 術前100cc當り19單位，24時間250單位から 衍後 $1 C 0 \mathrm{cc}$ 當り 5 單位, 24時間 140 單位に低下乞た。

Huggins 等は又19歳の時去勢された 30歳の男子につ

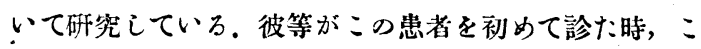
の忠者は既に數年間 testosterone propionate で治療さ れていたのであつて，最初の尿中フォスファターゼ測定 の前 2 カ月間を除いては，ずつと治療を續けていたので あろ。: の時尿中フォスフアターゼは $100 \mathrm{cc}$ 中平均 5 單 位で24時間100〜150單位であつた. testosterone propionate 每日25mg 3 週間使用したところ，尿中フォスフ アターゼ排出量は $100 \mathrm{cc}$ 中最大 15 單位に迄高まつた。

次に類宦官症について24蔵の兩側停留等丸及び28歳つ 兩側睪丸中等度萎縮の 2 人の尿フォスフアターゼを測定 そた，兩人共初めて診け時䀝に androgen 療法を續け ていたのであろが，尿中フォスフアターゼ量は共に不定 であつて testosterone propionate 使用を1 カ月以上中 止した後でも，去勢青年の昜合程低くはならなかった。 これはこの兩人共 androgen 使用前に充分發澾した前 立腺が存在していたのであり， androgenを分泌す万源 が全然無かっけわけではないからであると迅べている。

以上の試驗成績から Huggins 等は次の如く結論して いろ.

1）成人男子の尿中酸フォスフアターゼの䨘が高いっ は前立腺分泌液が混入するからである。

2）尿管尿は酵素の活性が低いが排出尿では高い。

3）成人で前立腺を除去すると尿中酵素量は低下 $i$, 尿管尿と同程度!迄減少す万. 正常青年の尿中酸フオス ファターゼ鏳加の大部分が前立腺から流出するのだと假 定すると每日見られろ尿中の捈んど一定の醭素量は, 每

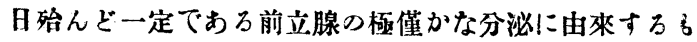


いであるということになる。

4) 前立腺上皮の分泌が androgen の刺戟に從屬し ていることと, 前立腺が尿中に出てくる酸フォスフアタ 一ゼの高い榎を有している場所であるということによつ て，尿中酻素の測定が男子に於ける androgen 活性の指 數並び!前立腺分泌の指數になる。

斯くて尿中酸フォスファターゼつ測定により前立腺分 泌の狀態を窅知しようとす万立場が展開した。

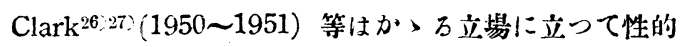
刺戟に二對す万前立腺分泌㙨能の反膲㹜態を研究するとと もに, 前立腺が男性ホルモンの刺戟に對し敏感な器官で あるところえら，尿中酸フォスフアターゼつ測定を通じ て性的發育の程度を測定した。气の大要は炏の如くであ 万. 彼等は Huggins と同漛 phenolphthalein phosphate 基筫とし，5人の男子 2 人つ女子! 猥哇映畫を觀覽さ せその前後の尿を探取し單位時間中つ酸フォスフアター 也排泄量を測定比較した，男子5人中 4 人は明かに增量 〔1人は反へて減少した。減少した 1 人は畫面に面喰つ て畫面を見ていなかつたためであると彼等は說明してい

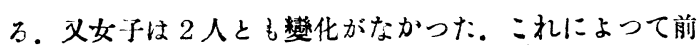
立腺は感情的刺戟に反㤰するものであると彼等に述べて いる。

次に彼等は 6 蔵から18歲に酉る202人(男103，女99)の 24 時間中の排泄全尿中の酸フォスフアターゼを浿定し， 併さて17-ketosteroid の分泌量をし測定とた。その結果 12歲䫁迄は男女殆んぞ同量の酸フオスフアターゼを排出 寸るが，12歲以後男子は女子より多く分泌するようにな り，完全に成熟すると男子は女子の 3.5 倍になる。尿中 17-ketosteroid と酸フォスフアターゼとは發育と共に墳 大寸万點で㮽括的!には本行しているが，個人差が比校的 に多く，從つて循環中の androgen によつて前立腺が 刺戟されるという點は, 可成つ個人差が認められると迅 べている.

以上症中酸フオスファターゼに靠する研究發展 の被過の概觀に於て次のことう明かになつた。

1. 尿中フォスフアターゼの大部分は酸フォス フアターゼであつて，アルカリフオスフアターゼ 䌽嚾少である。

2. マツサージにより得己れる前立腺液は尿中 酸フオスフアターゼと同一の酸フォスフアターゼ を大量に含有している.

3. 尿中酸フォスフアターゼの日來は赤血球の
航壞によるのでるなりれば腎によるのでもなく， 殆んど大部分が前立腺に゙起源をるつている.

4. 原中酸フォスフアターゼ排出量は女子では 㱠んぞ恒常的であるが，男子では日間に於ても月 間に於ても消長があつて恒常的でない.

5. 幼少時は男女共略々等量であるが, 思春期 頃ふら男子の方か：尿中酸フオスフアタ一ゼ排出量 の增加の割合が急で，成人に達すると男子は女子 の借になる、そして老年になると又減少する。

6. 男子の尿管尿乃至カテーテル尿は自然尿よ り酸フオスフアターゼ含有量が少く，大體女子の 自然尿に等しい.

7. 前立腺癌の轉移のある患者で沙血清中の酸 フォスフアターゼが增加し，尿中酸フォスフアタ 一ゼも增加する.

8. 性器の發育の惡いものでは尿中酸フォスフ アターゼの價も低い.

\section{III 私の實驗}

私は次の事項について测定した.

1. 1 日の間に於ける尿中酸アオスフアターゼ 分泌の消長。

2. 長時日の間の消重。

3. 前立腺マツサージ前後の排尿中の酸フォス ファターゼの價の此較。

4. 前立腺に外科的手術を施した際の前立腺分 泌の變化.

5. 類宦宫症及び男性假性牛除陽患兴について の测定.

6. 性的慾情が起つた際の前立脫分泌の變化.

7. ピロカルピン試驗に於ける前六腚分泌の變 化.

8. 前立腺分泌液の酸フオスフアターゼ含有量 は常に一定であるかどうか。

\section{1. 测定方法}

私は大體堀井赤松 ${ }^{28}$ (1943) の方法に從つて行つ た. その概略は次の通りである.

1）原理. 尿中の酸フオスフアターゼをグリセ

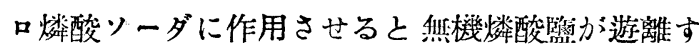
る. それにマグネシアを加えると $\mathrm{NH}_{4} \mathrm{Mg} \mathrm{PO}$ $6 \mathrm{H}_{2} \mathrm{O}$ の白色沈澱方起る。この洮澱か源尿をどの 
くらい稀釋したときに起るかるみれば，その酸つ オスフアターゼの量をしることができる。

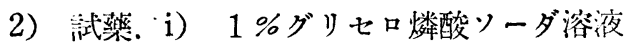

ii） $0.5 \%$ 醋酸浴液

iii） アンモンマグネシア混液

iv) 尿(溷濁あるもの统豫め演過し燐 酸嘕绣析により除去しておく)

3）操作. 30 分間法之 24 時間法とあ b. 前者の 結果が不碓實な場合げ行後者を施行する。

i）試驗管臺に10本の乾燥した小試驗管を立て 各管に $0.5 \%$ 醋酸溶液 $1.0 \mathrm{cc}$ 在入れる。

ii）第 1 , 第 2 試驗管に尿 $1.0 \mathrm{cc}$ 加气る.

iii）第 2 芸式驗管を无分に振盪しその $1.0 \mathrm{cc}$ を第 3 試驗管に移す。

iv）以下順次同樣の 2 倍稀釋を行い第 10 試驗管 に及方.

v）各管に $1.0 \%$ グリセロ燐酸ソーダ $1.0 \mathrm{cc}$ 加 え振壍する。

vi）なお別に對熙試驗として小試驗管に水 1.0 cc 尿 $1.0 \mathrm{cc}$ 加えたるのを用意する.

vii）試驗管咥にこれらの試驗管を立てたまま, $38^{\circ} \mathrm{C}$ の溫浴中に 30 分間浸溶する。

viii）次にこれを取りだし氷水中に浸して酵素 作用を中絕させアンモンマグネシア混液 $0.5 \mathrm{cc}$ を 加光る。

4）判定. 苚驗管中フォスフアターゼの作用を 受けなかつたものは透明で對照試驗管と同樣であ る。作用を受けた侙驗管は $\mathrm{NH}_{4} \mathrm{MgPO}_{4} 6 \mathrm{H}_{2} \mathrm{O}$ の白 色沈澱を生し，作用の强いるの程沈澱量が多い。

堀井氏の臨床的フォスフアターゼ 單位は對照試 驗管を標淮とし，それより1本前の試驗管の稀釋 度を以つてする。

$\begin{array}{ccc}\text { 試驗管番號 } & \text { 尿稀釋度 } & \text { 原尿含有量 } \\ \text { 對照 } & 1 & 1.0 \\ \text { I } & 1 & 1.0 \\ \text { II } & 2 & 0.5 \\ \text { III } & 4 & 0.25 \\ \text { IV } & 8 & 0.125 \\ \text { V } & 16 & 0.065 \\ \text { VI } & 32 & 0.032 \\ \text { VII } & 64 & 0.016 \\ \text { VIII } & 128 & 0.008 \\ \text { IX } & 256 & 0.004 \\ \text { X } & 512 & 0.002\end{array}$

アンモンマグネシア混液注入後 4 時間以上放㯰

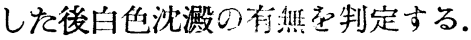

制定 $\mathrm{P}_{30}^{380}=2^{\mathrm{n}-1}\left(\mathrm{n} / \mathrm{\alpha}^{\circ}\right.$ 试驗管番號 $)$

5) 附記

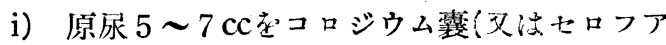
ン）中に入れ流水中に透析 $5 \sim 7$ 時間て略了完全 に燐酸渻を除去する。(24 時間なら完全)

ii）反應系の $\mathrm{pH}$ 注 4.2 4.6 であった.

iii）對照試驗管より1本前の試驗管の稀䆁度, 郎ち白色沈溊定生しさせうる最大稀釋度の尿中フ オスフアターゼの量汶 $1.3 \mathrm{mg} / \mathrm{dl}$ の燐酸を沈澱さ せるフォスフアターゼの量に一致した。郎ち, 1.3 Bodansky 單位(B.E)に一致した。 こして更に? の倍の稀釋について汶0.7 Bodansky 單位(B.E) に一致した。

iv）アンモンマグネシア混液の製法は次の通り である.

$\mathrm{MgCl}_{2} 6 \mathrm{H}_{2} \mathrm{O} \quad 11 \mathrm{~g} ： 1 \sim 2$ 日の後滤過して用い $\mathrm{NH}_{4} \mathrm{Cl} \quad 14 \mathrm{~g}$ る. この液 $10 \mathrm{cc}$ 在用いると $\mathrm{NH}_{3}(10 \%) \quad 70 \mathrm{cc}$ 約 $0.1 \mathrm{~g}$ の燐酸死沈澱させ 水 130cc ることがでる。

2. 测定結果

1）1日の間に於沙る㽷中酸フォスフアターゼ 分泌の消長

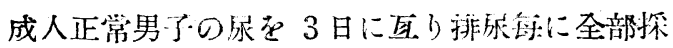
集し，その中の酸フォスフアターゼ量を測定した 結果は第 1 表及ざ第 1 圖に示す通りですつて，概 して朝排出量方高了午後核低くなってまり，夜間 も分泌か行われている。この說明として，i）早朝 勃起に件万前立腺分泌液增加，ii）夜間に排泄さ れた前立腺分泌液の膀胱內の貯溜，iii）i）之ii)の 兩方，という三つの考兑方がある. 晌 Wolbergs の耭拎試驗によると，血糖か低い時に增加すると いうから，饑䬺による影響す考光なくてはならな

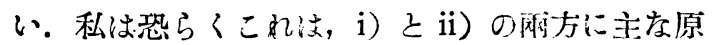
因があると考兑る。

2）長時日の間の消长

成人正常男子 8 名, 女子 1 名及ટ゙小㫕 2 名につ いて 1 力月間測定した結棵では（第 2 表, 第 2 圖) 成人男子に於て汶 1 日 50B.E 100B.Eの量力恒 * 
第 1 表 其D 1 . 定時探尿

\begin{tabular}{|c|c|c|c|c|c|c|c|c|c|c|}
\hline \multirow[b]{2}{*}{ H } & \multirow[b]{2}{*}{$\begin{array}{l}\text { 時 } \\
\text { 間 }\end{array}$} & I & 29歲 & 3 & II & 39歳 & 8 & III & 40歲 & $\hat{s}$ \\
\hline & & $\begin{array}{l}\text { 厡 } \\
\text { 量 } \\
\text { cc }\end{array}$ & $\begin{array}{l}\text { 酸才 } \\
\text { ᄀ量 } \\
\text { B. }\end{array}$ & $\begin{array}{c}1 \text { 分間 } \\
\text { 平均の } \\
\text { 酸フオ量 } \\
\text { B. E }\end{array}$ & $\begin{array}{l}\text { 厡 } \\
\text { 量 } \\
\text { CC }\end{array}$ & $\begin{array}{l}\text { 酸才 } \\
\text { ᄀ量 } \\
\text { B. }\end{array}$ & $\begin{array}{c}\text { 1分間 } \\
\text { 本均の } \\
\text { 酸フオ量 } \\
\text { B. E }\end{array}$ & $\begin{array}{l}\text { 厡 } \\
\text { 量 } \\
\text { C }\end{array}$ & $\begin{array}{l}\text { 酸7 } \\
\text { 才量 } \\
\text { B. }\end{array}$ & $\begin{array}{c}1 \text { 分間 } \\
\text { 本均の } \\
\text { 酸7オ量 } \\
\text { B. E }\end{array}$ \\
\hline \multirow[b]{2}{*}{ 第 } & \multirow[t]{2}{*}{4} & \multirow[t]{2}{*}{300} & \multirow[t]{2}{*}{14.40} & 0.034 & 370 & 23.68 & 0.056 & 400 & \multirow{2}{*}{38.40} & 0.092 \\
\hline & & & & 0.436 & & 26.88 & 0.149 & & & 0.684 \\
\hline \multirow[b]{2}{*}{1} & 10 & $\begin{array}{l}350 \\
320\end{array}$ & 78.40 & 0.142 & $\begin{array}{l}320 \\
300\end{array}$ & 72.00 & 0.400 & 400 & 172.80 & 0.960 \\
\hline & 13 & & 3256 & 0.181 & 500 & 12.00 & 0.145 & 400 & 172.00 & 0.356 \\
\hline \multirow{3}{*}{ 日 } & 10 & 370 & 32.50 & 0.110 & 310 & 20.04 & 0.138 & 320 & 64.00 & 0.280 \\
\hline & 17 & 300 & 26.40 & 0.085 & 350 & 33.00 & 0.159 & 350 & 67.20 & 0.260 \\
\hline & 21 & 350 & 20.30 & & 340 & 38.08 & & 300 & 62.40 & \\
\hline \multirow[b]{2}{*}{ 第 } & 4 & 380 & 42.56 & 0.101 & 360 & 144.00 & 0.343 & 370 & \multirow{2}{*}{44.40} & 0.106 \\
\hline & 7 & 350 & 75.60 & 0.420 & & \multirow{2}{*}{74.88} & 0.416 & \multirow{2}{*}{340} & & 0.095 \\
\hline 2 & 10 & 320 & 32.00 & 0.178 & $\begin{array}{l}360 \\
350\end{array}$ & & 0.187 & & 13.64 & 0.076 \\
\hline & 13 & 300 & 14.60 & 0.081 & 320 & 58.88 & 0.327 & 330 & 31.68 & 0.176 \\
\hline Н & 17 & 340 & 65.28 & 0.272 & 280 & 2.80 & 0.012 & 300 & 2400 & 0.100 \\
\hline & 21 & 320 & 15.36 & 0.064 & 350 & 67.20 & 0.280 & 320 & 1792 & 0.078 \\
\hline & 4 & 360 & & 0.163 & 220 & 127 20 & 0.327 & & & 0.638 \\
\hline 第 & & 300 & & 1.525 & 300 & 108.20 & 0.195 & 500 & 10.10 & 0.099 \\
\hline & $y$ & 330 & 274.56 & 0.171 & 350 & 35.00 & 0.341 & 370 & 17.76 & 0.039 \\
\hline 3 & 10 & 320 & 30.72 & 0.286 & 320 & 61.44 . & 0.083 & 280 & 7.00 & 0.673 \\
\hline & 13 & 280 & 51.52 & 0.146 & 310 & 14.88 & 0.068 & 300 & 13.20 & 0.058 \\
\hline 日 & 17 & 350 & 35.00 & 0273 & 340 & 16.32 & $0 \quad 015$ & 330 & 13.92 & 0,016 \\
\hline & 21 & 330 & 55.44 & 0.215 & 300 & 3.60 & & 340 & 3.74 & \\
\hline
\end{tabular}

第 1 表 其の 2 . 自然排尿時探尿

\begin{tabular}{|c|c|c|c|c|}
\hline \multirow[b]{2}{*}{ H } & & & & \\
\hline & $\begin{array}{l}\text { 時 } \\
\text { 間 }\end{array}$ & $\begin{array}{l}\text { 厡 } \\
\text { 量 } \\
\text { cc }\end{array}$ & $\begin{array}{c}\text { 酸フオ量 } \\
\text { B. E }\end{array}$ & \multirow[t]{2}{*}{$\begin{array}{c}\text { 1分間 } \\
\text { 平均D } \\
\text { 酸フオ冒 } \\
\text { B. E }\end{array}$} \\
\hline \multirow{3}{*}{$\begin{array}{l}\text { 第 } \\
1 \\
H\end{array}$} & 8 & 140 & 26.88 & \\
\hline & 13.5 & 220 & 21.12 & \multirow{2}{*}{$\begin{array}{l}0.064 \\
0.031\end{array}$} \\
\hline & 19.5 & 280 & 11.20 & \\
\hline \multirow[b]{2}{*}{ 第 } & 2 & 240 & 24.96 & \multirow{2}{*}{$\begin{array}{l}0.064 \\
0.061\end{array}$} \\
\hline & 10 & 260 & 29.12 & \\
\hline \multirow{3}{*}{2} & 13 & 300 & 7.20 & \multirow[b]{2}{*}{0.086} \\
\hline & 155 & 230 & 1280 & \\
\hline & 10.0 & 200 & 12.80 & \multirow{3}{*}{$\begin{array}{l}0.014 \\
0.056\end{array}$} \\
\hline \multirow{2}{*}{$\mathrm{H}^{\circ}$} & 20 & 360 & 20.00 & \\
\hline & 23.5 & 210 & 11.76 & \\
\hline \multirow{2}{*}{$\begin{array}{l}\text { 第 } \\
3 \\
\mathrm{H}\end{array}$} & 3 & 160 & 66.56 & \\
\hline & 11 & 250 & 24.00 & \\
\hline
\end{tabular}

第 1 圖 尿中フォスターゼ 1 日間の消長

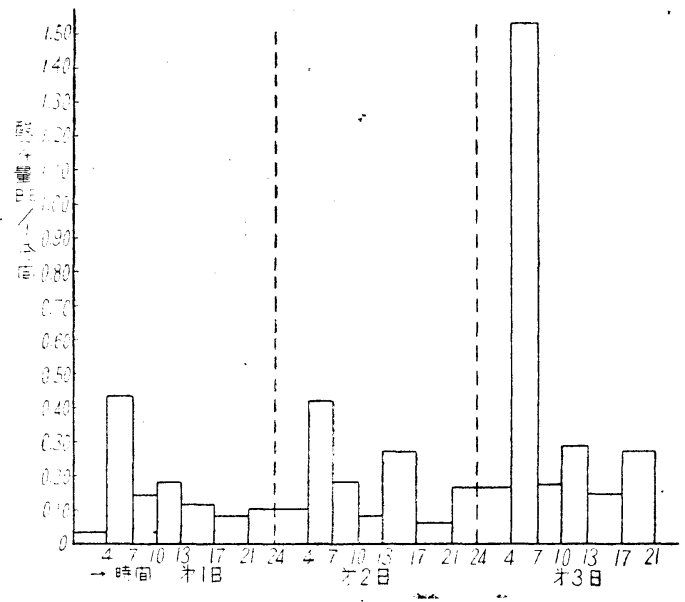




\begin{tabular}{|c|c|c|c|c|c|c|c|c|c|c|c|c|}
\hline 被檢者 & I & 36歲 & $\delta$ & II & 23歲 & $\hat{o}$ & & I 29歳 & $\hat{o}$ & IV & 34歲 & $\hat{o}$ \\
\hline & 尿 ${ }_{\mathrm{cc}}^{\text {量 }}$ & $\begin{array}{c}\text { 酸フォオ } \\
\text { 量 } \\
\text { B.E }\end{array}$ & $\begin{array}{l}\text { 酸ᄀオ量 } \\
\mathrm{B} . \mathrm{E} / \\
1 \text { 分間 }\end{array}$ & ${ }_{\mathrm{cc}}{ }^{\text {量 }}$ & $\begin{array}{c}\text { 酸フォ } \\
\text { 量 } \\
\text { B. E }\end{array}$ & $\begin{array}{l}\text { 酸フオ量 } \\
\mathrm{B.E} / \\
1 \text { 分間 }\end{array}$ & 尿 & $\begin{array}{c}\text { 酸フオ } \\
\text { 量 } \\
\text { B.E }\end{array}$ & $\begin{array}{l}\text { 酸フオ量 } \\
\text { B. E/ } \\
1 \text { 分間 }\end{array}$ & 尿 ${ }_{c c}^{\text {量 }}$ & $\begin{array}{c}\text { 酸フォ } \\
\text { 量 } \\
\text { B. } \mathrm{E}\end{array}$ & $\begin{array}{l}\text { 酸フオ量 } \\
\text { B. } \mathrm{E} / \\
1 \text { 分間 }\end{array}$ \\
\hline 第 1 日 & 1800 & 156.80 & 0.109 & 2010 & 176.88 & 0.123 & 1930 & 208.44 & 0.145 & 2060 & 115.36 & 0.080 \\
\hline 2 & & 114.52 & 0.080 & 2100 & 184.80 & 0.128 & 1970 & 204.88 & 0.142 & 1970 & 189.12 & 0.131 \\
\hline 3 & 1570 & 100.48 & 0.070 & 2030 & 97.44 & 0.068 & 1980 & 873.60 & 0.607 & 2050 & 98.40 & 0.068 \\
\hline 4 & 1500 & 61.68 & 0.043 & 2000 & 40.00 & 0.028 & 1950 & 202.80 & & 1890 & 158.76 & 0.110 \\
\hline 5 & 1450 & 57.40 & 0.040 & 1950 & 93.60 & 0.065 & 1900 & 98.80 & 0.069 & 1980 & 213.84 & 0.149 \\
\hline 6 & 1760 & 45.76 & 0.032 & 1980 & 110.88 & 0.077 & 1800 & 223.20 & 0.155 & 2010 & 209.04 & 0.145 \\
\hline 7 & 300 & 46.80 & 0.033 & 1950 & 97.50 & 0.068 & 1920 & 53.76 & & 80 & 190.08 & 0.132 \\
\hline 8 & 3720 & 51.60 & 0.036 & 2050 & 213.20 & 0.148 & 1980 & 229.68 & 0.1 & 1950 & 113.10 & 0.079 \\
\hline 9 & 1640 & 170.56 & 0.118 & 2020 & 121.20 & 0.084 & 1920 & 460.80 & & 1980 & 95.04 & 0.066 \\
\hline 10 & 1830 & 51.24 & 0.036 & 1970 & 110.32 & 0.077 & 1970 & 1702.08 & 1.182 & 1950 & 117.00 & 0.081 \\
\hline 11 & & 76.80 & & 1950 & 54.60 & 0.038 & 1980 & 1647.36 & & & 108.00 & 0.075 \\
\hline 12 & & 3.28 & & & 60.00 & & & & & & & \\
\hline 13 & 1600 & 44.80 & & 1950 & 105.30 & 0.073 & 1860 & 178 & & 2000 & 1184 & 0.082 \\
\hline 14 & & 149.60 & 0.1 & 1900 & 102.60 & 0.071 & 1950 & 436.80 & & 1950 & 101.40 & 0.070 \\
\hline 15 & & & & 2000 & 104 & 0.0 & & 116 & & & & 0.075 \\
\hline 16 & & & & & & & & & & & & \\
\hline 17 & & 5.20 & 0.020 & 20 & 864 & 0.600 & 2000 & 56.00 & & & 106.38 & 0.074 \\
\hline 18 & & & & & & & & 109 & & & & \\
\hline 19 & & & & & & & & & & & .20 & \\
\hline 20 & & & & 200 & 8.00 & 0. & 19 & 119.40 & & & 57.42 & 0.039 \\
\hline 21 & & & & 19 & & & & & & & & \\
\hline 2 & & & & & & & & 52 & & & & \\
\hline 23 & & & & & & & & & & & & \\
\hline 24 & & & 0.0 & 19 & & 0.127 & & 91 & & & 108.00 & 0.075 \\
\hline 25 & & & & & 87 & & & & & & & \\
\hline 26 & & & & & & & & & & & & 0.069 \\
\hline 27 & & & 0.0 & 18 & 190 & 0. & 20 & 108 & & & 109 & 0.076 \\
\hline 28 & & & & 19 & & & 19 & & & & & 0.032 \\
\hline 29 & & & 0.0 & 200 & & 0.069 & 1900 & & & 2010 & 402.00 & 0.279 \\
\hline 30 & 1080 & 28.08 & 0.020 & 1950 & 101.40 & 0.070 & 1900 & 76.00 & 0.053 & 1800 & 86.40 & 0.060 \\
\hline
\end{tabular}

第 2 圖 尿中フォスターゼ 1 筒月間の消長

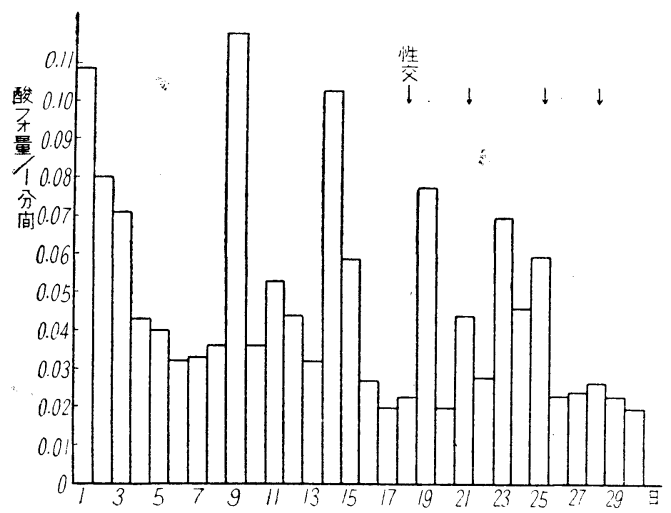

* 常的に排泄されている以外に，5〜 7 日おきに 200B.E乃至ミれ以上のピークか現われており，こ の山は性交を頻包(11 日間に 4 包)行うようになつ てから亂れてなくなつてふり，佮排泄量も減少し この減少沙最終性交後 2 日で恢復の徵をみせてい る.
女子の場合は 1 日量が 50 B.E前後であつて男子 のようなピークはみられない。

6 歲及び 3 歲の男子について 1 日量を测定した とこう各々 $20 \mathrm{~B} \mathrm{E}$ (0.014 B.E/ 1 分間)及び10B.E (0.007 B.E/ 1 分間)であつた. 又 77歲の正常男子. 高嶫者について测定したが別段猅泄量つ減少はる とめられ方，この點 Scott-Huggins の成績と一 致しな亦つた。

\section{小 括}

以上から私が知り得たことは

i）前立腺液の分泌は畫夜を間わす續けられて いる。むしろ夜間の方が多いかと思われる。

ii） 日間の變化を詳しくみると，千前殊に冚朝 に於て午後より多く分泌される。

Wolbergs ぶ3 時間我に探取した成績による之 正乍に採取した尿中に傼かに多くなつており，こ れを胡食から時がたつたための饑餓によるかるし れないと考えているか，これは寒理であつて，私 
表

\begin{tabular}{|c|c|c|c|c|c|c|c|c|c|c|c|c|c|c|}
\hline V & 39歲 & $\hat{o}$ & VI & 40蔵 & $\hat{\delta}$ & VII & 55蔵 & o & VII & II 77 歲 & $\hat{\delta}$ & IX & 28歲 & क \\
\hline $\begin{array}{l}\text { 尿量 } \\
\text { cc }\end{array}$ & $\begin{array}{c}\text { 酸フォオ } \\
\text { 量 } \\
\text { B.E }\end{array}$ & $\begin{array}{l}\text { 酸 } 7 \text { オ量 } \\
\text { B. E } \\
1 \text { 分間 }\end{array}$ & $\begin{array}{l}\text { 尿量 } \\
\text { Cc }\end{array}$ & $\begin{array}{l}\text { 酸ᄀ } \\
\text { 才量 } \\
\text { B.E } \\
\text { B. }\end{array}$ & 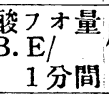 & $\begin{array}{l}\text { 尿量 } \\
\text { cc }\end{array}$ & $\begin{array}{l}\text { 酸 } 7 \\
\text { 量 } \\
\text { B. } \\
\text { B. }\end{array}$ & 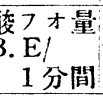 & $\begin{array}{l}\text { 尿量 } \\
\text { Cc }\end{array}$ & $\begin{array}{l}\text { 酸 } 7 \text { 酸 } \\
\text { 才量 B. } \\
\text { B. E }\end{array}$ & $\begin{array}{l}\text { 光オ量 } \\
\text { E/ 分間 }\end{array}$ & $\begin{array}{c}\text { 尿量 } \\
\text { Cc }\end{array}$ & $\begin{array}{c}\text { 酸ᄀオ } \\
\text { 量 } \\
\text { B.E }\end{array}$ & $\begin{array}{l}\text { 酸フ才量 } \\
\text { B. E/ } \\
1 \text { 分間 }\end{array}$ \\
\hline 1980 & 87.12 & 0.067 & 1990 & 166.96 & 0.116 & 1540 & 49.28 & 0.034 & 1460 & 81.76 & 0.057 & 1770 & 42.48 & 0.030 \\
\hline 2000 & 112.00 & 0.078 & 1990 & 111.44 & 0.077 & 1190 & 76.16 & 0.053 & 1080 & 30.24 & 0.021 & 1520 & 45.60 & 0.032 \\
\hline 1950 & 265.20 & 0.184 & 1980 & 110.88 & 0.077 & 1500 & 90.00 & 0.063 & 1600 & 46.40 & 0.032 & 1800 & 48.96 & 0.034 \\
\hline 2010 & 96.48 & 0.067 & 1920 & 92.16 & 0.064 & 1420 & 79.52 & 0.055 & 1520 & 170.24 & 0.118 & 2080 & 50.76 & 0035 \\
\hline 1910 & 95.50 & 0.066 & 2000 & 108.00 & 0.075 & 1030 & 53.56 & 0.037 & 1120 & 129.92 & 0.090 & 1880 & 52.64 & 0.037 \\
\hline 1950 & 48.75 & 0.034 & 1920 & 186.64 & 0.130 & & & & & & & $17 \mathrm{CO}$ & 41.48 & 0.029 \\
\hline 1980 & 229.68 & 0.110 & 1870 & 104.72 & 0.073 & & & & & & & 2080 & 41.60 & 0.029 \\
\hline 1930 & 69.48 & 0.048 & 2030 & 97.44 & 0.068 & & & & & & & 1490 & 38.74 & 0.027 \\
\hline 1800 & 57.60 & 0.040 & 1940 & 104.76 & 0.073 & & & & & & & 1400 & 33.60 & 0.023 \\
\hline 1950 & 249.60 & 0.173 & 2050 & 110.70 & 0.077 & & & & & & & 1520 & 39.52 & 0.027 \\
\hline 1920 & 522.24 & 0.363 & 1900 & 53.20 & 0.037 & & & & & & & 1640 & 39.36 & $0.027^{\circ}$ \\
\hline 1950 & 421.20 & 0.293 & 1960 & 407,68 & 0.283 & & & & & & & 1320 & 31.68 & 0.022 \\
\hline 1840 & 412.16 & 0.286 & 2000 & 104.00 & 0.072 & & & & & & & 1800 & 43.20 & 0.030 \\
\hline 1580 & 42.66 & 0.030 & 1850 & 96.20 & 0.067 & & & & & & & 1320 & 31.68 & 0.022 \\
\hline $19=0$ & 103.48 & 0.072 & 1820 & 45.50 & 0.032 & & & & & & & 1520 & 45.60 & 0032 \\
\hline 1950 & 56.55 & 0.039 & 2000 & 108.00 & 0.075 & & & & & & & 1140 & 36.48 & 0.025 \\
\hline 1840 & 51.52 & 0.036 & 2000 & 464.00 & 0.322 & & & & & & & & & \\
\hline 1870 & 48.62 & 0.034 & 2010 & 209.04 & 0.145 & & & & & & & & & \\
\hline 1920 & 51.84 & 0.036 & 1950 & 105.30 & 0.073 & & & & & & & & & \\
\hline 1910 & 99.32 & 0.069 & 1980 & 99.00 & 0.069 & & & & & & & & & \\
\hline 1920 & 92.16 & 0.064 & 1970 & 189.12 & 0.131 & & & & & & & & & \\
\hline 1970 & 189.12 & 0.131 & 1980 & 47.52 & 0.033 & & & & & & & & & \\
\hline 1910 & 99.32 & 0.069 & 2050 & 43.05 & 0.030 & & & & & & & & & \\
\hline 1900 & 110.20 & 0.077 & 1930 & 46.32 & 0.032 & & & & & & & & & \\
\hline 1940 & 104.76 & 0.073 & 1950 & 89.70 & 0.062 & & & & & & & & & \\
\hline 1870 & 104.72 & 0.073 & 1950 & 113.10 & 0.079 & & & & & & & & & \\
\hline 194 & 89.24 & 0.062 & 2000 & 84.00 & 0.058 & & & & & & & & & \\
\hline 1830 & 183.00 & 0.127 & 1970 & 181.24 & 0,126 & & & & & & & & & \\
\hline 1820 & 182.00 & 0.126 & 1930 & 96.50 & 0.057 & & & & & & & & & \\
\hline 1880 & 165.44 & 0.115 & 1950 & 101.40 & 0.070 & & & & & & & & & \\
\hline
\end{tabular}

は早朝勃起に原因を求もたいと照う。

iii）前立腺以外方らの分泌汢女子・場合から考 えて大體恒常的にあるか，前立腺分泌怯時々大量 にあると考えてよい，性交を繰り返えすとこの川 が低くなることから，性慾か高去つたときにこの 川か現われるのかもしれない. Wolbergs をこの 山の存存を認めているが，Scott-Huggins は分泌 の週期的增減をなす樣子はないといつている。

jv）尿中酸フォスフアターゼ量を测定して，己 の多㙞をいわんとするには，隨時に探つたのでは 男子の場合非常に䇠があり，1日量を测定しても 日により特に多い日があるから，注程壃重でなけ ればならない。估膀胱からカテーテルで㽷を探つ ても，必すしも前立腺分泌液のまじらない疗を得 られるわけでないこに，悡が探つたカテーテル

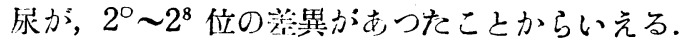
この點も注意しなければならない。この装の原因 は，前立腺分泌液ぶ逆流して膀胱尿にっじつてい
ることもあるであるうし，カテーテルで後部尿道 にある分化液を膀脱內におしこむこともあるであ らう. Scott-Huggins も同樣の經驗をしており， この原因めテーテルでおしこむことに求めてい 3.

v）思秦期前の小兒では尿中酸フォスフアター ゼの價が低く，思春期以後急に高くなるという Clark 等の所見を私も破認した. こして老年にな ると下るという Scott-Huggins の所見を私も追試 したか，私の少い例に於ては老年といえども特に 低いとはいわれなかつた。

vi）成人男子の尿中酸フォスフアターゼは成人 女子の數倍(Wolbergs $3 \sim 5$ 倍, Scott-Huggirs 4 倍) 强い力價がある。私が测定したところでは 平常の力價は大體 2 ４倍であるが，1 日の中で 或時間(多くは夜間や军朝)に探取した尿では特に 高いことがあり，又1カ月連䋶测定では特に高い 價を示す日があり，その最高價をとれば數十倍に 
なるのであつて，一律に何倍とはいえない。

3）前立鿟マツサージ前後の排尿中の酸フオス フアターゼの價の比較

前立腺に疾患のない成人男子 4 人について前立 腺マツサージを行い。 その前後に 2 杯分尿法によ り排尿させ各々について测定した結果は等 3 表の 通りマツサージ後斷然フォスフアターゼが增量し ていることが明かであつて, 分泌液が尿道口から 出る出ないに闒係がな。郎ちマツサージして液

第 3 表 前立腺マッサージ前後つ自然排尿 $1 \mathrm{cc}$ 中の酸フォスフアターゼ量

\begin{tabular}{|c|c|c|c|c|c|c|}
\hline \multirow{2}{*}{$\begin{array}{l}\text { 被 } \\
\text { 檢 } \\
\text { 者 }\end{array}$} & \multicolumn{2}{|c|}{ マッサージ前 } & \multicolumn{2}{|c|}{ マッサーシ 後 } & \multirow{2}{*}{$\mid \begin{array}{l}\text { マツサー } \\
\text { シにより } \\
\text { 流出さる } \\
\text { 分泌液 }\end{array}$} & \multirow{2}{*}{$\begin{array}{l}\text { 最近の } \\
\text { 射 精 }\end{array}$} \\
\hline & 前尿 & 後戚 & 前尿 & 後尿 & & \\
\hline 33歳 今 & & $2^{1}$ & $2^{9}$ & $2^{8}$ & + & 不 \\
\hline 25藏占 & $2^{3}$ & $2^{3}$ & $2^{9}$ & $2^{9}$ & + & 不 明 \\
\hline 27藏 今 & & $2^{3}$ & & $2^{10}$ & $\mathrm{HH}$ & 5 日前 \\
\hline 35歳含 & & $2^{2}$ & & $2^{10}$ & - & 7 日前 \\
\hline
\end{tabular}

引疗道から出ないものも，液の分泌がないのでは ないことがかかる. 又2 杯分疗法で同じ程度に排 泄されていることから，大部分の液が，殊に外尿 道口から排出のないるのは膀肬に逆流しているも のであることぶわかる。

倘 Kutscher 及び Scott-Huggins が尿中の酸 フォスフアターゼの大部分のものの起源は，前立 腺であるということを證明しているが，この私の 行つを方法も一つの礁實な證明法である，尿中の 價が血液中に比し，及び男子が女子に比し著るし く高いことがあるのも，この原因によるのであ る.

4）前立腺に外科的手術を施した際の前立腺分 泌の變化

i）前立腺肥大症にて 前立腺を完全に剔除した 2 例に於て，2例とも尿中酸フォスフアターゼは 激減し, Scott-Huggins の所見と全く一致したが 前立腺の被脱下剔除を行い被膜を殘した 5 例に於 ては，尿中酸フオスフアターゼは何れす減少しな かつた。（第 $4 ， 5$ 表及び第 $3 ， 4$ 圖）

第 4 表 前立腺肥大症に前立腺完全剔除術を施行し尿中酸フォ量が激減した例

\begin{tabular}{|c|c|c|c|c|c|c|c|}
\hline & & I & 72蔵 & $\hat{\beta}$ & II & 81歲 & $\hat{\delta}$ \\
\hline & & $\begin{array}{l}\text { 尿 量 } \\
\text { cc }\end{array}$ & $\begin{array}{l}\text { 酸フ木量 } \\
\text { B. E }\end{array}$ & $\begin{array}{l}\text { 酸フオ量 } \\
\text { B. E/ } 1 \text { 分間 }\end{array}$ & $\begin{array}{c}\text { 尿 }{ }^{\text {量 }} \\
\end{array}$ & $\begin{array}{c}\text { 酸フオ量 } \\
\text { B.E }\end{array}$ & $\begin{array}{l}\text { 酸フオ量 } \\
\text { B.E/ } 1 \text { 分間 }\end{array}$ \\
\hline 手 術 前 & $\begin{array}{l}3 \mathrm{H} \\
2 \\
1\end{array}$ & $\begin{array}{l}1200 \\
1100 \\
150 J\end{array}$ & $\begin{array}{l}134.40 \\
510.40 \\
168.00\end{array}$ & $\begin{array}{l}0.093 \\
0.354 \\
0.117\end{array}$ & & & \\
\hline 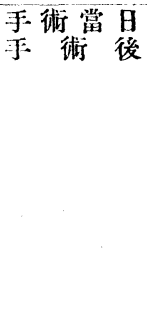 & $\begin{array}{c}1 \text { 日 } \\
2 \\
3 \\
4 \\
5 \\
6 \\
7 \\
8 \\
9 \\
10\end{array}$ & $\begin{array}{r}1300 \\
550 \\
1000 \\
1000 \\
900 \\
800 \\
800 \\
750 \\
800 \\
850 \\
720\end{array}$ & $\begin{array}{c}\text { 血液混入 } \\
55.00 \\
31.00 \\
32.00 \\
26.10 \\
24.00 \\
25.60 \\
23.25 \\
25.60 \\
61.20 \\
21.60\end{array}$ & $\begin{array}{l}0.038 \\
0.022 \\
0.022 \\
0.018 \\
0.017 \\
0.018 \\
0.016 \\
0.018 \\
0.043 \\
0.015\end{array}$ & $\begin{array}{r}\text { 血液 } \\
\\
1010 \\
1600 \\
800 \\
1300 \\
1100 \\
1000\end{array}$ & $\begin{array}{r}15.15 \\
16.00 \\
9.60 \\
16.90 \\
11.00 \\
13.00\end{array}$ & $\begin{array}{l}0.011 \\
0.011 \\
0.007 \\
0.012 \\
0.008 \\
0.009\end{array}$ \\
\hline & $\begin{array}{l}11 \\
12 \\
13 \\
14 \\
15 \\
16 \\
17 \\
18 \\
19 \\
20 \\
21 \\
22\end{array}$ & $\begin{array}{r}1350 \\
1200 \\
1550 \\
1300 \\
1300 \\
1100 \\
1650 \\
1950 \\
2000 \\
1500 \\
1200 \\
500\end{array}$ & $\begin{array}{l}48.60 \\
42.80 \\
43.40 \\
32.50 \\
37.70 \\
30.80 \\
46.20 \\
52.65 \\
48.00 \\
40.50 \\
33.60 \\
19.00\end{array}$ & $\begin{array}{l}0.034 \\
0.030 \\
0.030 \\
0.023 \\
0.026 \\
0.021 \\
0.032 \\
0.037 \\
0.033 \\
0.028 \\
0.023 \\
0.013\end{array}$ & $\begin{array}{l}900 \\
800\end{array}$ & $\begin{array}{r}16.20 \\
9.60\end{array}$ & $\begin{array}{l}0.011 \\
0.007\end{array}$ \\
\hline
\end{tabular}




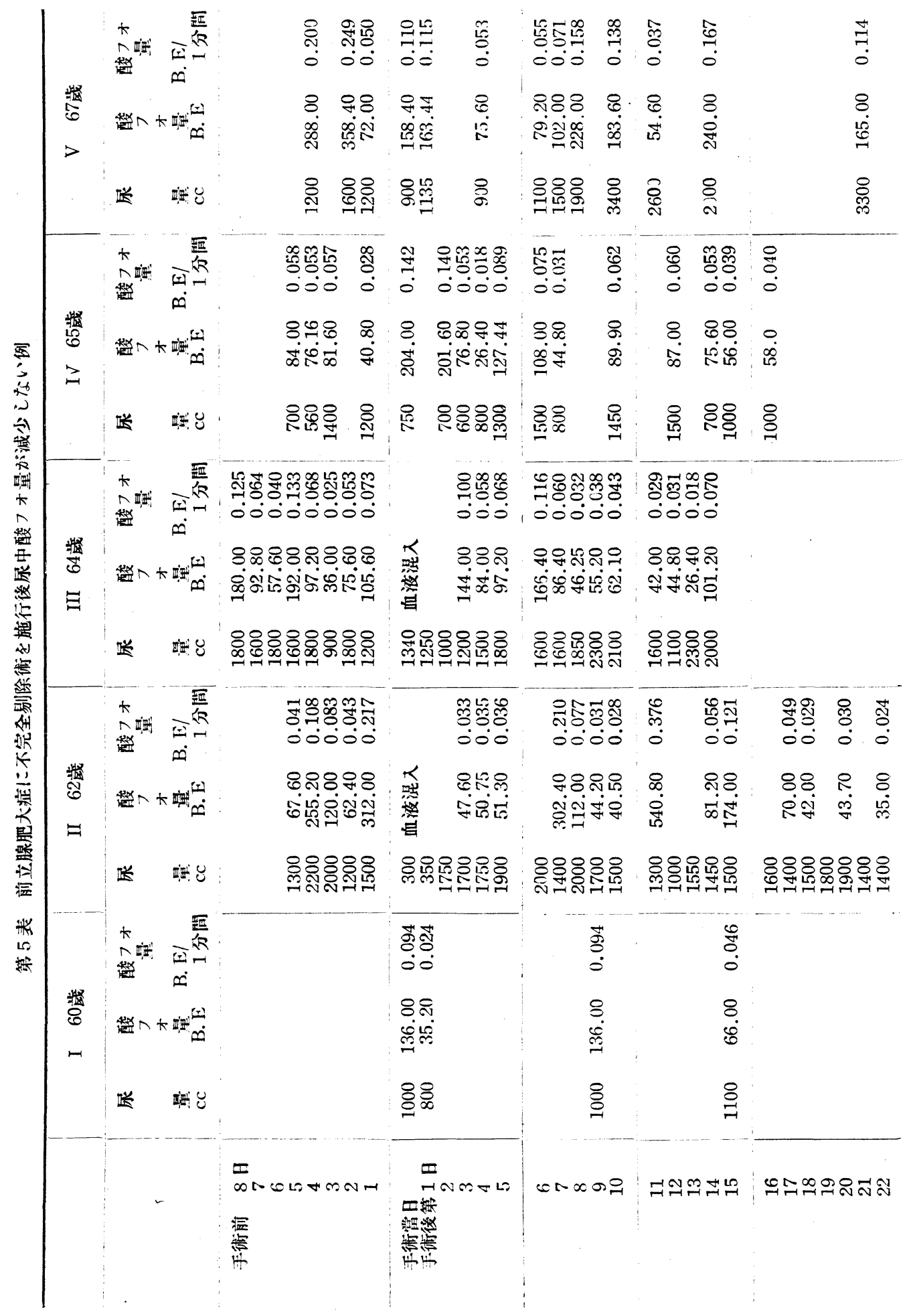


第 3 圖前立腺肥大症!二前立腺完全剔除術主施 行に尿中フォ量が激减した例

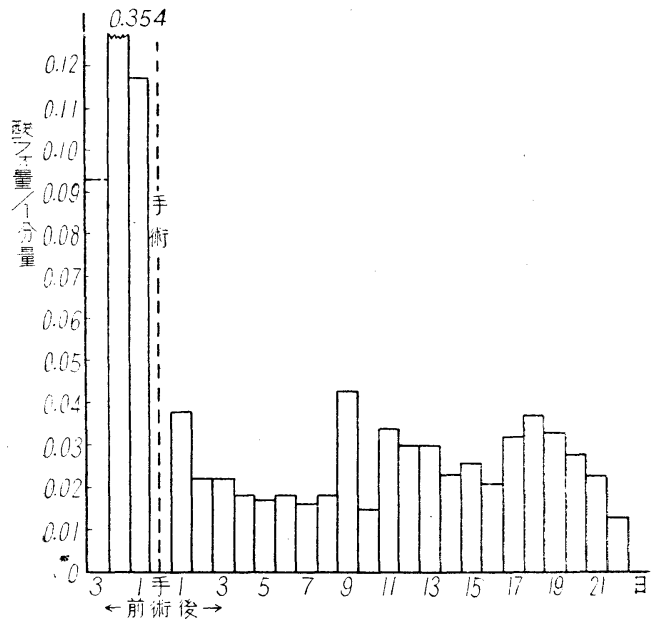

第 4 圖 前立腺肥火症!二前立腺不完全剔除術を 施行し尿中フ才量が減少こない例

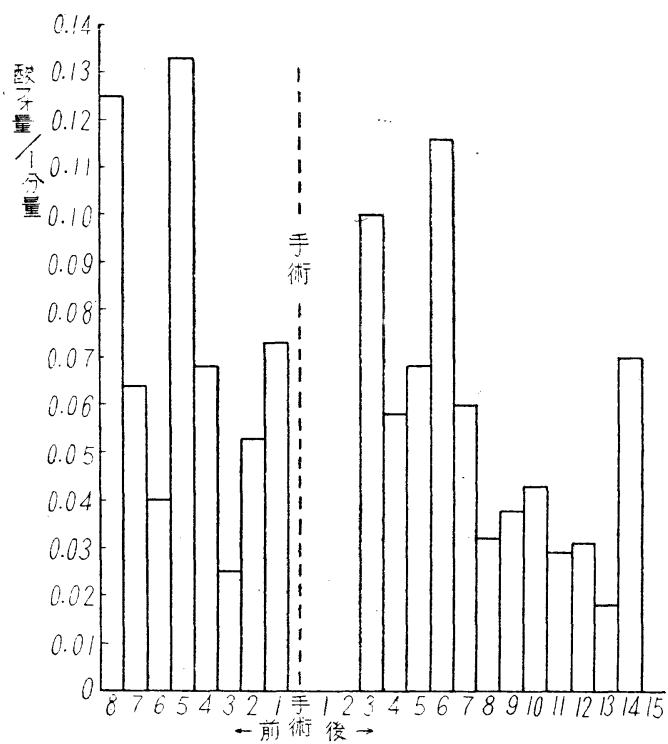

第 6 表 前立腺㾇に前立腺剔除術主施行し，尿中酸フオ量が激減（1）

及び不㘘 $(2)$ の例

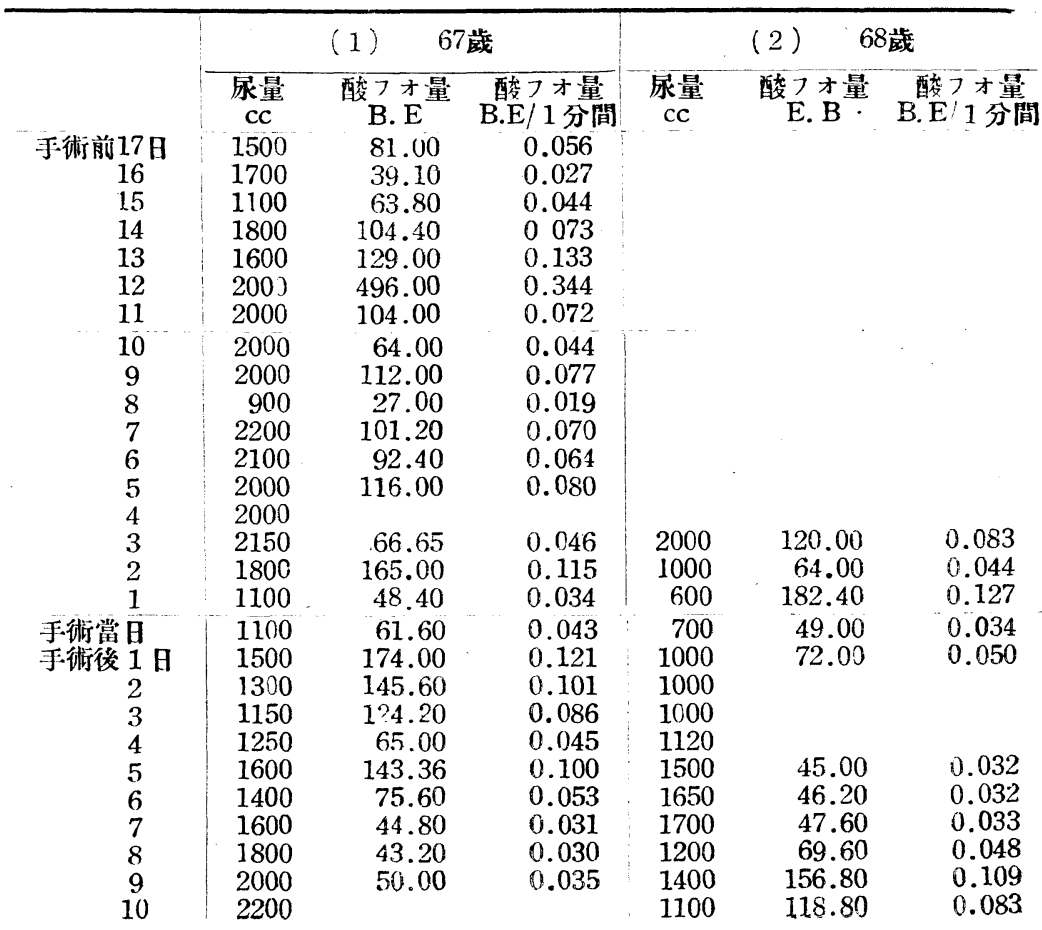




\begin{tabular}{lrrr|rrr}
\hline 11 & 1400 & 36.40 & 0.025 & 1.50 & 32.20 & 0.022 \\
12 & 1600 & 40.00 & 0.028 & 1800 & 48.60 & 0.034 \\
13 & 1800 & 43.20 & 0.030 & 1800 & 48.60 & 0.034 \\
14 & 1650 & 39.60 & 0.028 & 2100 & 58.80 & 0.041 \\
15 & 1800 & 43.20 & 0.030 & 2400 & 67.20 & 0.047 \\
16 & 1700 & 39.10 & 0.027 & 1800 & 48.60 & 0.034 \\
17 & 1600 & 43.20 & 0.030 & 2200 & 52.80 & 0.037 \\
19 & 1500 & 36.60 & 0.025 & 1900 & 49.40 & 0.034 \\
19 & 1500 & 36.00 & 0.025 & 1500 & 36.00 & 0.025 \\
20 & 700 & 20.30 & 0.014 & 1300 & 41.60 & 0.029 \\
\hline 21 & & & & 1600 & 41.60 & 0.029 \\
22 & & & & 1600 & 41.60 & 0.029 \\
23 & & & & 1700 & 47.60 & 0.033 \\
21 & & & & 1800 & 93.60 & 0.063
\end{tabular}

ii）前立腺剔除を行つた前正腺癌の 2 例に於て 1 例冷完剔除を行い，他の1例心一部組䄉が残 つたと照われたのであるが，前者に於て浪㽷中酸

第 5 圖前立腺揊!二前立腺别除術を施行し 尿中 フォ量が激減した例

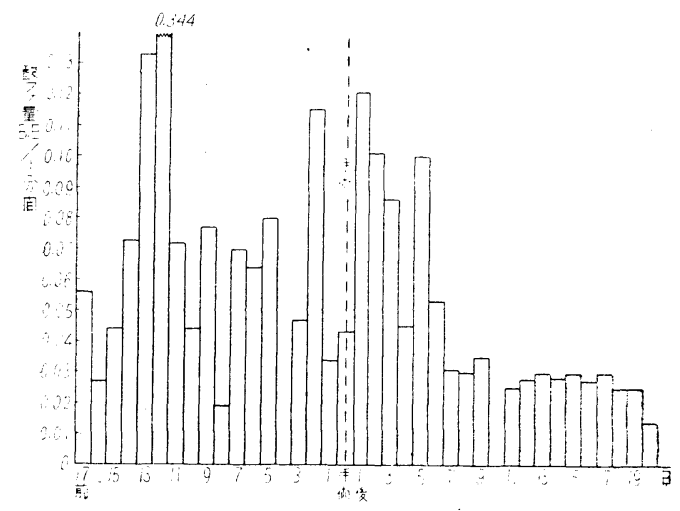

フオスフアターゼは激減し，後者に於ては減少は 見られなかつた。（第 6 表及び第 $5 ， 6$ 潩).

第 6 圖前立腺澏!前立腺剔除術を施行乞尿中 フォ量が不變の例

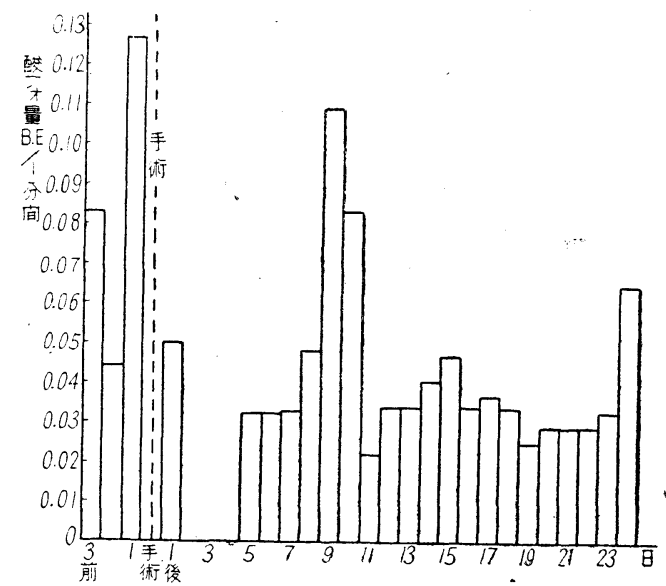

iii）文性ホル モンを總計1160 谣單位投與 し隐 床的に特别の好 結果を得られな 汃な前立腺癌 01 例（第 1 尼 0560 寍單位の 注射は著效があ つた)に於ては, 㞗中酸フオスフ アターゼも何等 の影響も認めら 第 7 圆 前立腺癌て女性ホルモン注射では影響なくラドン㨂入で 一時㽷中酸フオ量が減少をした例

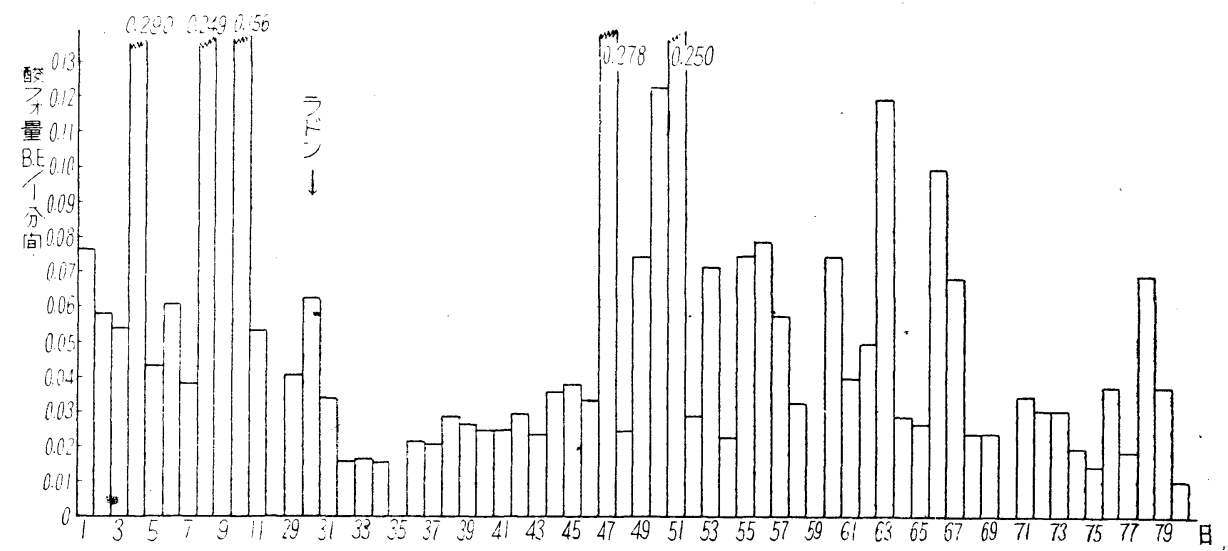
れなかつた。只この患者にラドンを雨入した際， ねみた。（第 7 表及び第 7 阔） 一特的に約 17 日第尿中酸フォスフアターゼの減少 
第 7 表 前立腺癌で女性ホルモン注射で影響なくラドン針打込で

一時尿中酸フオ量が減少を示した例。64歳

\begin{tabular}{|c|c|c|c|c|c|c|c|c|c|}
\hline $\begin{array}{l}\text { 檢 } \\
\text { 查 } \\
\text { 日 }\end{array}$ & $\begin{array}{l}\text { 曆 } \\
\text { 日 }\end{array}$ & $\begin{array}{l}\text { 尿量 } \\
\text { Cc }\end{array}$ & $\begin{array}{c}\text { 酸フオ量 } \\
\text { B. }\end{array}$ & $\begin{array}{c}\text { 酸フオ量 } \\
\text { B.E/ } 1 \text { 分間 }\end{array}$ & $\begin{array}{l}\text { 憸 } \\
\text { 查 } \\
\text { 日 }\end{array}$ & 曆 & $\begin{array}{c}\text { 尿量 } \\
\text { CC }\end{array}$ & $\begin{array}{c}\text { 酸フオ量 } \\
\text { B. }\end{array}$ & $\begin{array}{l}\text { 酸フオ量 } \\
\text { B.E/ } 1 \text { 分間 }\end{array}$ \\
\hline 1 & $25 / \mathrm{V}$ & $20<0$ & 112.00 & 0.077 & 41 & 4/VII & 1200 & 36.00 & 0.025 \\
\hline 2 & 26 & 1500 & 84.00 & 0.058 & 42 & 5 & 1500 & 43.50 & 0.030 \\
\hline 3 & 27 & 1400 & 78.40 & 0.054 & 43 & 6 & 1300 & 35.10 & 0.024 \\
\hline 4 & 28 & 1800 & 417.60 & 0.290 & 44 & 7 & 2000 & 52.00 & 0.036 \\
\hline 5 & 29 & 1100 & 61.60 & 0.043 & 45 & 8 & 2000 & 54.00 & 0.038 \\
\hline 6 & 30 & 1000 & 88.00 & 0.061 & 46 & 9 & 1800 & 48.60 & 0.034 \\
\hline 7 & 31 & 900 & 54.00 & 0.038 & 47 & 10 & 2000 & 400.00 & 0.278 \\
\hline 8 & $1 / \mathrm{VI}$ & 800 & 358.00 & 0.249 & 48 & 11 & 1500 & 36.00 & 0.025 \\
\hline 9 & 2 & 1100 & & & 49 & 12 & 1800 & 108.00 & 0.075 \\
\hline 10 & 3 & 1000 & 224.00 & 0.156 & 50 & 13 & 3400 & 176.80 & 0.123 \\
\hline 11 & 4 & 1400 & 78.40 & 0.054 & 51 & 14 & 36.0 & 360.00 & 0.250 \\
\hline 12 & 5 & & & & 52 & 15 & $1 \varsigma 00$ & 41.40 & 0.029 \\
\hline 13 & 6 & & & & 53 & 16 & 2000 & 104.00 & 0.072 \\
\hline 14 & 7 & & & & 54 & 17 & 1170 & 33.93 & 0.023 \\
\hline 15 & 8 & & & & 55 & 18 & 970 & 108.64 & 0.075 \\
\hline 16 & 9 & & & & 56 & 19 & 2030 & 113.63 & 0.079 \\
\hline 17 & 10 & & & & 57 & 20 & 1500 & 84.00 & 0.058 \\
\hline 18 & 11 & & & & 58 & 21 & 900 & 46.80 & 0.033 \\
\hline 19 & 12 & & & & 59 & 22 & 900 & 417.60 & 0.290 \\
\hline 20 & 13 & & & & 60 & 23 & 1000 & 108.00 & 0.075 \\
\hline & 14 & & & 7 & 61 & 24 & 400 & 57.60 & 0.040 \\
\hline 22 & 15 & & & 1 & 62 & 25 & 600 & 72.00 & 0.050 \\
\hline 23 & 16 & & & & 63 & 26 & 600 & 172.80 & 0.120 \\
\hline 24 & 17 & & & & 64 & 27 & 600 & 42.00 & 0.029 \\
\hline 25 & 18 & & & & 65 & 28 & 650 & 39.00 & 0.027 \\
\hline 26 & 19 & & & & 66 & 29 & 1400 & 145.00 & 0.100 \\
\hline 27 & 20 & & & & 67 & 30 & 950 & 98.80 & 0.069 \\
\hline 28 & 21 & & & & 68 & 31 & 1500 & 34.50 & 0.024 \\
\hline 29 & 22 & 800 & 59.20 & 0.041 & 69 & 1/VII & 1500 & 34.50 & 0.024 \\
\hline 30 & 23 & 600 & 91.20 & 0.063 & 70 & 2 & 2500 & & \\
\hline 31 & 24 & 1000 & 35.00 & 0.024 & 71 & 3 & 2000 & 50.00 & 0.035 \\
\hline 32 & 25 & 800 & 23.20 & 0.016 & 72 & 4 & 1650 & 44.55 & 0.031 \\
\hline 33 & 26 & 800 & 24.00 & 0.017 & 73 & 5 & 1650 & 44.55 & 0.031 \\
\hline 34 & 27 & 900 & 22.50 & 0.016 & 74 & 6 & 900 & 28.80 & 0.020 \\
\hline 35 & 28 & 800 & & & 75 & 7 & 1500 & 21.00 & 0.015 \\
\hline 36 & 29 & 1070 & 32.10 & 0.022 & 76 & 8 & 1000 & 54.00 & 0.038 \\
\hline 37 & 30 & 1000 & 30.00 & 0.021 & 77 & 9 & 1000 & 27.00 & 0.019 \\
\hline 38 & 1/VII & 1450 & 42.05 & 0.029 & 78 & 10 & 900 & 100.80 & 0.070 \\
\hline 39 & 2 & 1400 & 39.20 & 0.027 & 79 & 11 & 900 & 54.24 & 0.038 \\
\hline 40 & 3 & $12 C 0$ & 36.00 & 0.025 & 80 & 12 & 550 & 16.50 & 0.011 \\
\hline
\end{tabular}

以上の結果として， 尿中酸フオスフアターゼの 測定を，前立腺剔除術の完全さや女性ホルモン投 與及びラドン㨂入の效力の有無の制定に役立たせ ることかでさるわけである。

5）類宦官症及び 男性假性牛㓌陽患者について の测定

この兩者ともに正常男子より低價を示し（第 8， 9 表), 前:者は胹下垂體移植により輕度の增加があ つたようである. 後者は高度の牛除陽で睪丸はあ つたが右側は發育不良で且つ腹腔內に停留してお り，示指がやつと根部迄入るような腔らしいもの る認め，前立腺は觸診し得なかつた患者であつて
患者のたつての希望により睪丸，除鱼を剔除した この後の测定値であるが，殆んど测定することが できない程の少量しか排泄されていなかつた。郎 ら尿中酸フオスフアターゼを测定することにより これらの男性性器發育不良患者の前立腺發育の程 度を，或程度迄數值的に示すことができる。

9）性的慾情が起つた際の前立腺分泌の變化 私はストリツプショウの觀劇及び性的刺钱讀書 の方法を以つて性的感情を起させ，その前後一定 時間內の排尿中の酸フオスフアターゼを测定比較 したのであるが，ミの成績は第10，11表及び第 8 9 罳の如くである。郎ち荍劇者 12 人中 10 人は明 * 
第 8 表 類宦官症!䐉下垂體を移植した前後の比較

\begin{tabular}{|c|c|c|c|c|c|c|}
\hline & \multicolumn{3}{|c|}{ I $\quad 27$ 蔵 } & \multicolumn{3}{|c|}{ II 23翽 } \\
\hline & $\begin{array}{l}\text { 尿量 } \\
\text { cc }\end{array}$ & $\begin{array}{c}\text { 酸フオ量 } \\
\text { B. E }\end{array}$ & $\begin{array}{c}\text { 酸フォ量 } \\
\text { B.E/1 }\end{array}$ & $\begin{array}{c}\text { 尿量 } \\
\text { cc }\end{array}$ & $\begin{array}{c}\text { 酸ᄀ オ量 } \\
\text { B. } \mathrm{E}^{-1}\end{array}$ & $\begin{array}{c}\text { 酸フォ量 } \\
\mathrm{B.E} / 1 \text { 分成 }\end{array}$ \\
\hline $\begin{array}{c}\text { 移植前第15日 } \\
14 \\
13 \\
12 \\
11 \\
10 \\
9\end{array}$ & $\begin{array}{r}1000 \\
980 \\
850 \\
800 \\
1500 \\
1200 \\
1000\end{array}$ & $\begin{array}{r}30.00 \\
54.88 \\
25.50 \\
44.80 \\
78.00 \\
124.80 \\
52.00\end{array}$ & \begin{tabular}{l|}
0.021 \\
0.038 \\
0.018 \\
0.031 \\
0.054 \\
0.087 \\
0.036
\end{tabular} & & & \\
\hline 移植 $\begin{array}{c}2 \\
1 \\
\text { 移植後第 } 1 \text { 日 }\end{array}$ & $\begin{array}{l}1300 \\
1500 \\
1300 \\
1200 \\
1200\end{array}$ & $\begin{array}{l}29.90 \\
51.00 \\
39.00 \\
36.00 \\
33.60\end{array}$ & $\begin{array}{l}0.021 \\
0.035 \\
0.028 \\
0.025 \\
0.033\end{array}$ & $\begin{array}{r}1500 \\
650 \\
1250 \\
1300\end{array}$ & $\begin{array}{l}90.00 \\
42.90 \\
70.00 \\
57.20\end{array}$ & $\begin{array}{l}0.063 \\
0.030 \\
0.049 \\
0.040\end{array}$ \\
\hline $\begin{array}{l}15 \\
16 \\
17 \\
18 \\
19 \\
20 \\
21\end{array}$ & $\begin{array}{l}1200 \\
1050\end{array}$ & $\begin{array}{l}163.20 \\
138.10\end{array}$ & $\begin{array}{l}0.113 \\
0.096\end{array}$ & 1200 & 72.00 & $\begin{array}{l}0.050 \\
0.0555\end{array}$ \\
\hline
\end{tabular}

第 9 表 男性假性牛陰陽患者

\begin{tabular}{|c|c|c|}
\hline $\begin{array}{l}\text { 手術後 } \\
\text { 日 數 }\end{array}$ & ${ }_{\mathrm{cc}}{ }^{\text {量 }}$ & $\begin{array}{c}\text { 酸フオ量 } \\
(\text { (刵定做) } \\
\text { Pn-1 }\end{array}$ \\
\hline 第 1 H & 1300 & $2^{\circ}$ \\
\hline 2 & 900 & $2^{\circ}$ \\
\hline 3 & 1000 & $2^{\circ}$ \\
\hline 4 & 1100 & $2^{\circ}$ \\
\hline
\end{tabular}

(酸フォスフアターゼ量過少にて測定不能)

第10表 ストリップショウ觀覽前後の 尿中酸フオ量の比洨

\begin{tabular}{|c|c|c|c|c|}
\hline \multirow{2}{*}{$\begin{array}{l}\text { 被 } \\
\text { 㗂 }\end{array}$} & \multicolumn{2}{|c|}{ 前 } & \multicolumn{2}{|c|}{ 後 } \\
\hline & $\begin{array}{c}\text { 排尿量 } \\
\text { Cc }\end{array}$ & $\begin{array}{c}\text { 酸フオ量 } \\
\text { B. } \mathrm{E}^{-1}\end{array}$ & $\begin{array}{c}\text { 排尿量 } \\
\text { cc }\end{array}$ & $\begin{array}{c}\text { 酸了才量 } \\
\text { B. E }\end{array}$ \\
\hline I & 55 & 0.83 & 120 & 6.24 \\
\hline II & 15 & 0.19 & 160 & 7.68 \\
\hline III & 150 & 3.45 & 580 & 11.60 \\
\hline IV & 105 & 2.52 & 400 & 8.80 \\
\hline V & 110 & 4.62 & 300 & 14.40 \\
\hline VI & 100 & 2.30 & 150 & 7.20 \\
\hline VII & 265 & 6.10 & 480 & 19.20 \\
\hline VIII & 300 & 15.00 & 175 & 30.80 \\
\hline IX & 200 & 10.40 & 230 & 22.08 \\
\hline X & 160 & 16.64 & 75 & 33.60 \\
\hline XI & 250 & 6.25 & 140 & 3.78 \\
\hline XII & 210 & 40.32 & 90 & 4.68 \\
\hline
\end{tabular}

*かに尿中酸フオスフアターゼの增加を見，2人 のみは減少を見た。減少した 1 人は事前の想像興 奪が强度であつたためではないかと洘えられる。
㯖書の場合は被检者 8 人全部が尿中酸フォスフア ターゼの著明な增加を示した。この結果から，か 第 8 圖 ストリツプショウ觀覽前後の比較

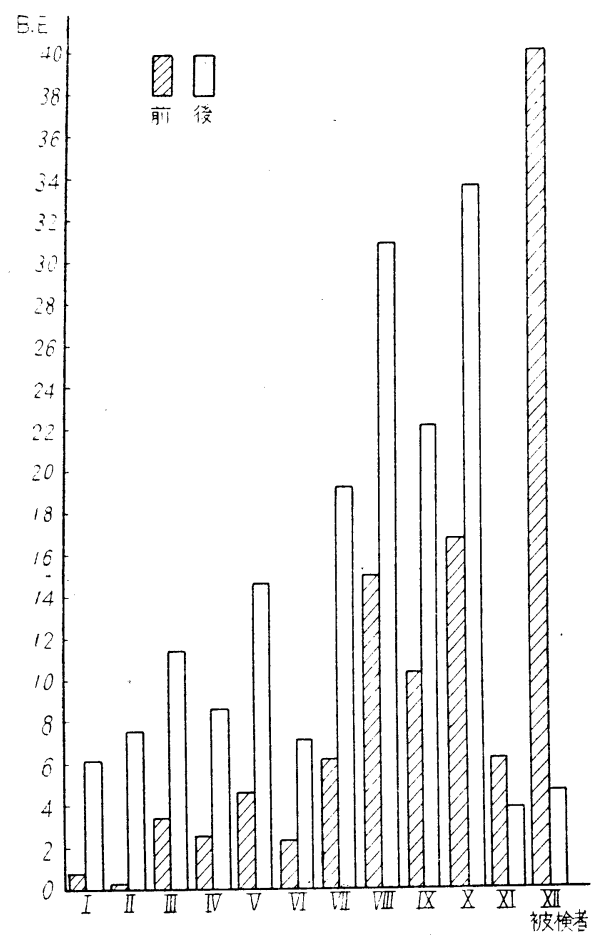


第11表 性的刺戟讀書前後の尿中酸フオ量の比校 （前後各 2 時間の排尿!こつき檢查す）

\begin{tabular}{|c|c|c|c|c|c|c|}
\hline \multirow[b]{2}{*}{$\begin{array}{l}\text { 被 } \\
\text { 檢 } \\
\text { 奢 }\end{array}$} & \multicolumn{3}{|c|}{ 前 } & \multicolumn{3}{|c|}{ 後 } \\
\hline & $\begin{array}{l}\text { 排尿 } \\
\text { 量 } \\
\text { cc }\end{array}$ & $\begin{array}{c}\text { 酸 } 7 ~ \\
\text { 量 } \\
\text { B. E }\end{array}$ & $\begin{array}{c}\text { 酸フオ量量 } 1 \text { 分間 } \\
\end{array}$ & $\begin{array}{c}\text { 排尿 } \\
\text { 量 } \\
\text { cc }\end{array}$ & $\begin{array}{c}\text { 酸フォ } \\
\text { 量 } \\
\text { B. E }\end{array}$ & $\begin{array}{c}\text { 酸フォ量 } \\
\text { / } 1 \text { 分間 }\end{array}$ \\
\hline I & 130 & 6.24 & 0.052 & 120 & 23.04 & 0.192 \\
\hline II & 265 & 6.10 & 0.051 & 850 & 17.00 & 0.142 \\
\hline III & 55 & 3.08 & 0.026 & 205 & 9.02 & 0.075 \\
\hline IV & 40 & 2.08 & 0.017 & 60 & 6.72 & 0.056 \\
\hline V & 210 & $10.9 z$ & 0.091 & 108 & 22.46 & 0.187 \\
\hline II & $51^{i 1}$ & $10 .{ }^{\circ} 0$ & 0.085 & 360 & 57.60 & 0.480 \\
\hline VII & 115 & 6.44 & 0.054 & 135 & 13.50 & 0.113 \\
\hline VIII & 260 & 6.76 & $\begin{array}{ll}0 & 056\end{array}$ & 390 & 156.00 & 0.130 \\
\hline
\end{tabular}

第 9 圖 性的刺戟讀萻前後の比輘

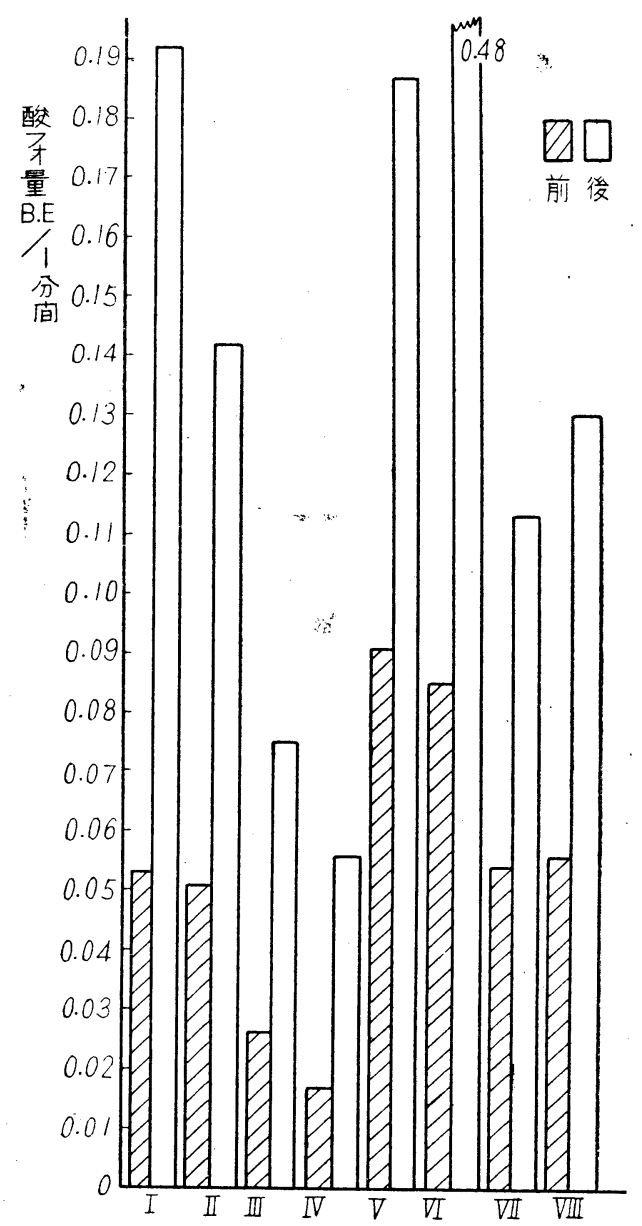

つる觀劇及び讀書により前立腺の分泌は明かに增 加すると考えてよい：そして私は尿中酸フォスフ アターゼを测定することにより劇，讀書等の性的 慾情刺敦の程度を大略推定できると考えるのであ
る. 性的刺㦸があれば前立腺の分泌力增加するこ とは常識的にも考えられることであつて，この示 糟として尿中酸フォスフアターゼを選んだの法悡 が世界に於て薃矢であると考えていたとこう，こ の䂰劣終了後最近に至つて Clark等加私の研究さ 同じ賎同樣の政究を行い，悡と同じ結果を得てい ること苍發表しているのを知つた。

この方法法法學的應用も洘えられる。

7）ピロカルピン試驗に於ける前立腺分泌心變 化

5 人の健㡺青年男子について侙驗した。唾液の 分泌はピロカルピン注射後 10分川至20分で最高す 示し，40 分乃至50分からはほとんど平常にもどる ところから，注射直前と注射後 30 分及び 1 時間で 排尿させ，三れ以後は隨意の時に排尿させて採尿 し，尿中酸フオスフアターゼを测定した. 三の成

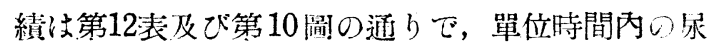

第12表 ピロカルピン試驗

( $1 \%$ 監酸ピロカルピン0.1cc/kg)

\begin{tabular}{|c|c|c|c|c|}
\hline $\begin{array}{l}\text { 被 } \\
\text { 檢 } \\
\text { 者 }\end{array}$ & $\begin{array}{ll}\text { ピピ } & \text { 時 } \\
\text { ロ } & \\
\text { カ } & \text { 間 }\end{array}$ & $\begin{array}{c}\text { 尿量 } \\
\text { cc }\end{array}$ & $\begin{array}{c}\text { 酸フォ } \\
\text { 量 } \\
\text { B. E }\end{array}$ & $\begin{array}{r}\text { 酸フォ量 } \\
\text { /1分間 }\end{array}$ \\
\hline $\begin{array}{c}\text { I } \\
27 \text { 歳 } \\
\widehat{o}\end{array}$ & $\begin{array}{r}6^{\circ} 20^{\prime} \\
9^{\circ} 15^{\prime} \\
\rightarrow 10^{\circ} 55^{\prime} \\
11^{\circ} 25^{\prime} \\
11^{\circ} 55^{\prime} \\
14^{\circ} 10^{\prime} \\
18^{\circ} 00^{\prime}\end{array}$ & $\begin{array}{r}150 \\
8 ? \\
80 \\
40 \\
20 \\
80 \\
135\end{array}$ & $\begin{array}{l}7.80 \\
1.97 \\
1.92 \\
1.92 \\
2.08 \\
1.92 \\
3.38\end{array}$ & $\begin{array}{l}0.011 \\
0.019 \\
0.064 \\
0.069 \\
0.014 \\
0.014\end{array}$ \\
\hline $\begin{array}{c}\text { II } \\
21 \text { 歳 } \\
\hat{o}\end{array}$ & $\begin{array}{r}7^{\circ} 30^{\prime} \\
-11^{\circ} 15^{\prime} \\
11^{\circ} 45^{\prime} \\
12^{\circ} 15^{\prime} \\
15^{\circ} 30^{\prime} \\
22^{\circ} 30^{\prime}\end{array}$ & $\begin{array}{r}230 \\
150 \\
35 \\
48 \\
190 \\
280\end{array}$ & $\begin{array}{r}31.28 \\
16.80 \\
31.36 \\
12.67 \\
4.94 \\
7.28\end{array}$ & $\begin{array}{l}0.075 \\
1.045 \\
0.422 \\
0.025 \\
0.009\end{array}$ \\
\hline \begin{tabular}{c} 
III \\
23 歳 \\
\multirow{8}{*}{}
\end{tabular} & $\begin{array}{r}7^{\circ} 10^{\prime} \\
\rightarrow 10^{\circ} 50^{\prime} \\
11^{\circ} 20^{\prime} \\
11^{\circ} 50^{\prime} \\
15^{\circ} 25 \prime \\
7^{\circ} 00^{\prime}\end{array}$ & $\begin{array}{r}300 \\
110 \\
20 \\
26 \\
175 \\
315\end{array}$ & $\begin{array}{r}7.80 \\
10.56 \\
8.00 \\
9.98 \\
4.03 \\
6.30\end{array}$ & $\begin{array}{l}0.048 \\
0.267 \\
0.333 \\
0.019 \\
0.030\end{array}$ \\
\hline $\begin{array}{c}\text { IV } \\
23 \text { 歳 } \\
\hat{\delta}\end{array}$ & $\begin{array}{r}8^{\circ} 40^{\prime} \\
\rightarrow 11^{\circ} 15^{\prime} \\
11^{\circ} 45^{\prime} \\
12^{\circ} 15^{\prime} \\
14^{\circ} 15^{\prime} \\
19^{\circ} 30^{\prime}\end{array}$ & $\begin{array}{r}675 \\
135 \\
52 \\
46 \\
90 \\
275\end{array}$ & $\begin{array}{r}13.50 \\
3.24 \\
6.03 \\
2.02 \\
2.34 \\
6.33\end{array}$ & $\begin{array}{l}0.022 \\
0.201 \\
0.068 \\
0.020 \\
0.020\end{array}$ \\
\hline $\begin{array}{c}\mathrm{V} \\
25 \text { 歳 } \\
\hat{\jmath}\end{array}$ & $\rightarrow \begin{array}{r}7^{\circ} 15^{\prime} \\
11^{\circ} 15^{\prime} \\
11^{\circ} 45^{\prime} \\
12^{\circ} 15^{\prime} \\
14^{\circ} 50^{\prime}\end{array}$ & $\begin{array}{r}345 \\
165 \\
48 \\
50 \\
170\end{array}$ & $\begin{array}{r}19.32 \\
7.59 \\
2.21 \\
2.30 \\
4.42\end{array}$ & $\begin{array}{l}0.032 \\
0.074 \\
0.075 \\
0.030\end{array}$ \\
\hline
\end{tabular}


中酸フォスフアターゼ排出量は注射後 30 分乃至 1 時間に於て明かに增加しており，人により 30 分迄 の尿中量が最高となるもあり，1時間迄のそれぶ 最高となるものもある。從つて前立腺の分泌治ピ ロカルピン注射により一時增加するということ㧍 だきる。

第10圖 ピロカルピン試驗

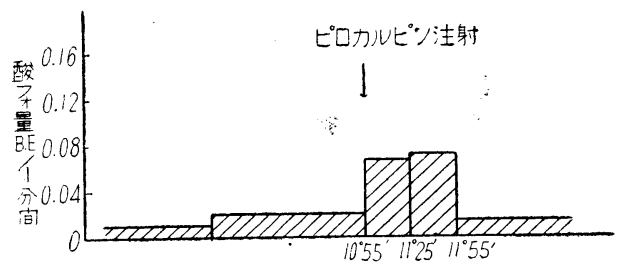

同じ 5 人についてピロカルピンを注射する直前 前立腺マツサージを行い排尿させて，一應前立腺 內貯溜液を全部排出させた後ビ口カルピン侙驗を 施し， 30 分及び 1 時間後に排尿させて尿中酸フォ スフアターゼを测定したのであるが，任然注射後

第13表 前立腺マッサージ直後ピロカルピン試驗 $(0.1 \mathrm{cc} / \mathrm{kg})$

\begin{tabular}{|c|c|c|c|c|c|}
\hline $\begin{array}{l}\text { 被 } \\
\text { 檢 } \\
\text { 者 }\end{array}$ & $\begin{array}{l}\text { 前ツ及カ注 } \\
\text { 立サびル } \\
\text { 腺、ヒビ } \\
\text { マジン }\end{array}$ & 時 & $\begin{array}{l}\text { 尿量 } \\
\mathrm{cc}\end{array}$ & $\begin{array}{c}\text { 酸フォ } \\
\text { 量 } \\
\text { B.E }\end{array}$ & $\begin{array}{l}\text { 酸フォ } \\
\text { 量/1分間 }\end{array}$ \\
\hline $\begin{array}{c}\text { I } \\
20 \text { 藏 } \\
\text { 今 }\end{array}$ & $\rightarrow$ & $\begin{array}{l}6^{\circ} 30^{\prime} \\
10^{\circ} 00^{\prime} \\
11^{\circ} 45^{\prime} \\
12^{\circ} 15^{\prime} \\
12^{\circ} 45^{\prime} \\
14^{\circ} 30^{\prime}\end{array}$ & $\begin{array}{r}100 \\
80 \\
38 \\
30 \\
90\end{array}$ & $\begin{array}{r}2.70 \\
276.48 \\
6.38 \\
12.48 \\
2.52\end{array}$ & $\begin{array}{l}0.013 \\
2.625 \\
0.213 \\
0.416 \\
0.02 i\end{array}$ \\
\hline $\begin{array}{c}\text { II } \\
21 \text { 藏 } \\
\hat{\delta}\end{array}$ & $\rightarrow$ & $\begin{array}{r}7^{\circ} 100^{\prime} \\
9^{\circ} 30^{\prime} \\
11^{\circ} 45^{\prime} \\
1.015^{\prime} \\
12^{\circ} 45^{\prime} \\
16^{\circ} 30^{\prime} \\
\end{array}$ & $\begin{array}{r}75 \\
54 \\
39 \\
3 i \\
110 \\
\end{array}$ & $\begin{array}{r}5.10 \\
331.78 \\
18.10 \\
1.75 \\
3.08 \\
\end{array}$ & $\begin{array}{l}0.034 \\
2.765 \\
0.603 \\
0.058 \\
0.013\end{array}$ \\
\hline $\begin{array}{c}\text { III } \\
23 \text { 藏 } \\
3\end{array}$ & $\rightarrow$ & $\begin{array}{r}0^{\circ} 20^{\prime} \\
10^{\circ} 20^{\prime} \\
11^{\circ} 50^{\prime} \\
12^{\circ} 20^{\prime} \\
12^{\circ} 50^{\prime} \\
14^{\circ} 30^{\prime}\end{array}$ & $\begin{array}{r}280 \\
248 \\
50 \\
34 \\
180\end{array}$ & $\begin{array}{c}29.12 \\
730.11 \\
5.00 \\
1.97 \\
8.64\end{array}$ & $\begin{array}{l}0.049 \\
8.112 \\
0.167 \\
0.066 \\
0.086\end{array}$ \\
\hline $\begin{array}{l}\text { IV } \\
23 \text { 歳 } \\
\hat{o}\end{array}$ & $\rightarrow$ & $\begin{array}{l}6^{\circ} 50^{\prime} \\
10^{\circ} 20^{\prime} \\
10^{\circ} 50^{\prime} \\
11^{\circ} 20^{\prime} \\
14^{\circ} 48^{\prime} \\
16^{\circ} 35^{\prime}\end{array}$ & $\begin{array}{r}300 \\
70 \\
30 \\
35 \\
385 \\
280 \\
\end{array}$ & $\begin{array}{r}15.60 \\
483.84 \\
24.96 \\
7.28 \\
61.60 \\
1400 \\
\end{array}$ & $\begin{array}{l}2.419 \\
0.832 \\
0.243 \\
0.293 \\
0.133\end{array}$ \\
\hline $\begin{array}{c}\mathrm{V} \\
25 \text { 歳 } \\
3\end{array}$ & $\rightarrow$ & $\begin{array}{l}8^{\circ} 30^{\prime} \\
11^{\circ} 50^{\prime} \\
12^{\circ} 20^{\prime} \\
12^{\circ} 50^{\prime} \\
18^{\circ} 05\end{array}$ & $\begin{array}{r}435 \\
152 \\
32 \\
44 \\
308\end{array}$ & $\begin{array}{r}24.36 \\
544.77 \\
6.40 \\
4.58 \\
17.25\end{array}$ & $\begin{array}{l}2.724 \\
0.213 \\
0.153 \\
0.069\end{array}$ \\
\hline
\end{tabular}

30 分少至 1 時間に於て前立腺の分泌がるれた。 佾导の量脑サージしないときより多いものも 少いものもあつて一定しない，郎ち第13表及び第 11 浴の通りである。

第11圖 前立腺マツサージ直後ピロカルピン試驗

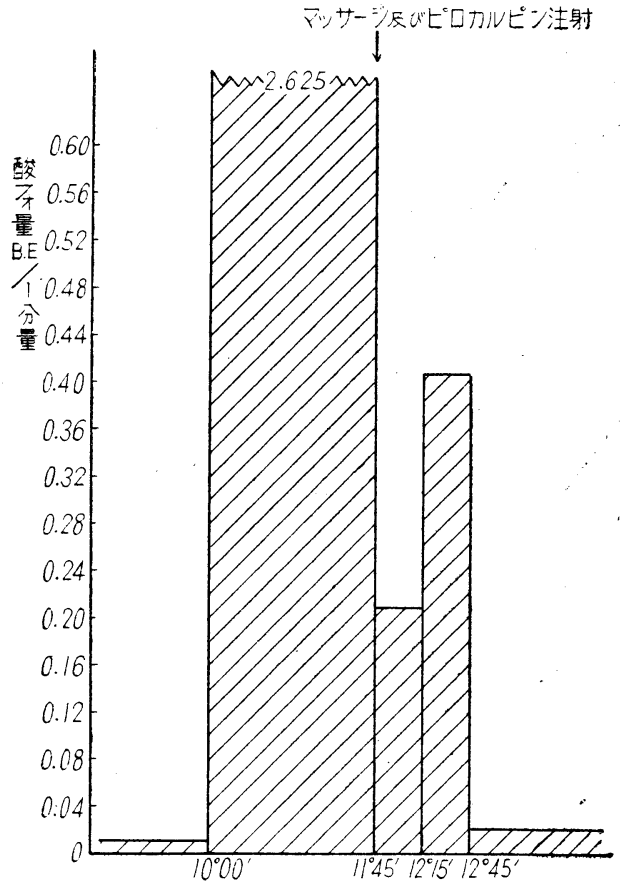

第14表 前立腺膈患者にに於けるピロカルピン試驗 63 藏 $\hat{0}$

\begin{tabular}{|c|c|c|c|c|}
\hline $\begin{array}{l}ヒ^{\circ} ヒ ゚ \\
ロ \\
カ y \\
\text { ル 注 }\end{array}$ & $\begin{array}{l}\text { 時 } \\
\text { 間 }\end{array}$ & $\begin{array}{c}\text { 尿 量 } \\
\mathrm{cc}\end{array}$ & $\begin{array}{c}\text { 酸フオ量 } \\
\text { B. } \mathrm{E}\end{array}$ & $\begin{array}{l}\text { 酸フォ } \\
\text { 量/1分間 }\end{array}$ \\
\hline$\rightarrow$ & $\begin{array}{r}8^{\circ} 30^{\prime} \\
10^{\circ} 1 C^{\prime} \\
10^{\circ} 4 C^{\prime} \\
11^{\circ} 10^{\prime} \\
12^{\circ} 4 C^{\prime}\end{array}$ & $\begin{array}{l}40 \\
45 \\
30 \\
75\end{array}$ & $\begin{array}{l}1.84 \\
5.04 \\
3.24 \\
3.75\end{array}$ & $\begin{array}{l}0.018 \\
0.168 \\
0.108 \\
0.042\end{array}$ \\
\hline
\end{tabular}

第12圖 前立腺癌患者!於け万ピロカルピン試驗

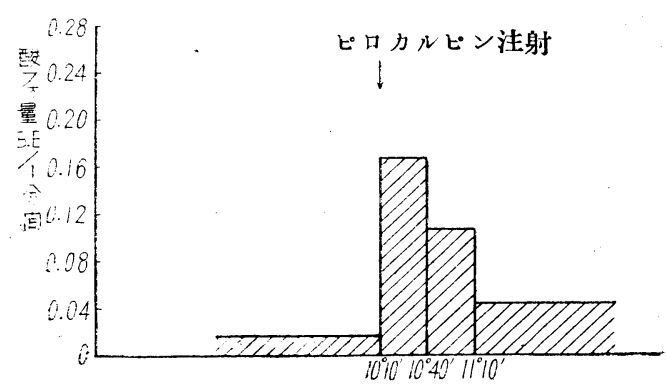


又前立腺癌の 1 例についてピロカルピン試驗を 行つた成績は第14表及び第12圖の逥りで, 健康者 の場合と全く同樣の成績が得られた。

8）前立腺分泌液の酸フォスフアタ一ゼ含倠量 は常に一定であるか否かを確定するため，私は犬 を用いて動物實驗を行つた。

體重 $10 \mathrm{~kg}$ の犬の膀胱项部, 精管を結紮し尿道を 切斷してその求心部を體外に引き出し，之にガラ ス管を挿入して 前立腺分泌液を直接探取できるよ うにして，30 分間隔にて $1 \%$ 暨酸ピロカルピン 1 cc 在靜脈注射し，排出する前立腺分泌液を15分府: に别個の試驗管に探取し，その比重並びに酸フオ スフアターゼ量を测定したのであるが，その成績 は第15表の如くで，肉眼的には時間とともに急速

第15表 犬に於けろヒロロルヒン静洼による 前立腺分泌試驗 (犬の體重 $10 \mathrm{~kg}$ )

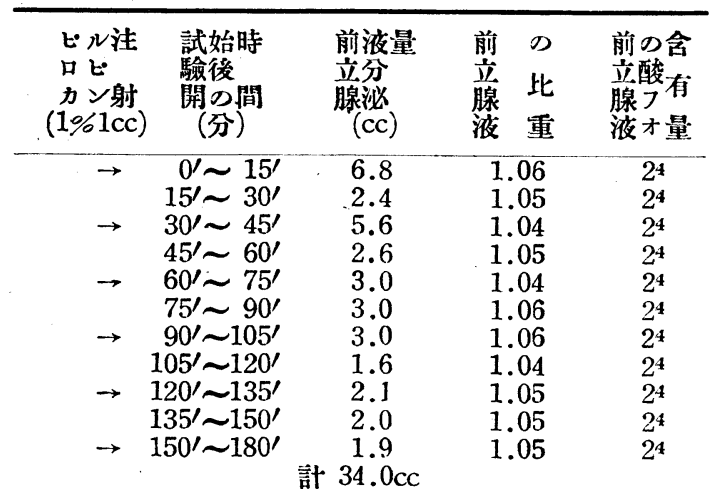

に透明度を增し，1時間目頃からは全く透明とな つたのであるが，比重及び酸フォスフアターゼ含 有量は終始殆んぞ一定であつた。 そしてビロカル ピンを $6 \mathrm{cc}$ 注射したときを最後に，郎ち試驗開始 後 3 時間で犬は死ししたが，前立腺分泌液は最後 まで殆んど同じ分量で分泌されつづけた。

\section{IV. 總 括}

1. 尿中酸フオスファターゼの测定により成人 男子の前立腺の分泌狀況を檢枉し，更に外科的手 術, 精神的刺㦸, 藥物等の影響による前立腺分泌 の變化の狀態を檢查した。

2. 前立腺分泌液は畫夜たえす分泌され，早朝 に特に多い。

3. 隹日恒常的に分泌されるが，數日敷に特に
多い日がある。これは性慾の立進と關係があるか をしれない。

4. 前立腺マツサージ後は尿中酸フォスフアタ 一ゼが急增する。これは本酵素の起源が前立腺で むるという證明の一助になる。

5. 類宦官症及び男性假性牛㓌陽では 分泌が少 く，前者では腦下垂體移植により秒ら增加した。 師ち本测定法は前立腺發育の程度をきめることに 役立つ.

6. 前立腺肥大症及び癌の何れに於ても，外科 的手術により前立腺を完全に剔除した場合は前立 腺の分泌は激減し，不完全剔除で被膜等の組織が 一部殘つた場合は前立腺の分泌は減少しない。

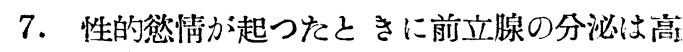
まる. 從つてこれは法醫學上の應用が考えられる。

8. ピロカルピン試驗に於て唾液分泌之相件つ て注射後 30 分乃至 1 時間で前立腺の分泌も增加す る. ただしその相互の量的關係が平行するわけで はない. 又ピロカルピン注射直前に前立腺マツサ 一ジを施行し前立腺詝溜液を无分排出させたあと でも，前立腺の分泌はこの注射に應して增加する。

9. 犬にピロカルピンを靜脈注射して前立腺分 泌液を連續採取したところ，犬は死ぬまで全く同 じ程度に分泌しつづけ，しかも分泌液は次第に透 明度を增したにもかかわらず比重站びに酸フオス フアターゼ含有量は終始略ら一定であつた.

10. estrogen の大量注射の影響はないが, ラド ンによる疗中酸フォスフアターゼ排泄低下ふふるら れた。

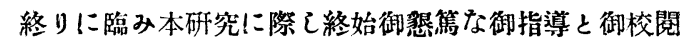
つ勞を賜つた市川教授!に深甚な謝意を表と，又種々御助 言と御鞭婞を戴いた大越助教授及び材料蒐集其の他萬般 !に絕大な御援助を下さつけ泌尿器科教室の各位!:衷心か ら感謝する。

\section{玄獻}

1) Euler: Z. f. Phys. Chem., 74, 13, 1911. - 2) Zaleski: Ber. d. deutsch. bot. Ges., 24, 285, 1906. -3) Harden-Young: Proc. of Royal Soc. Ser. B., 82, 321, 1910.-4) Neuberg-Pollak: Bioch. Z., 23, 515, 1910. -5) Embden: Z. f. Phys. Chem., 93, 124, 1914.-6) Nemec: Bioch. Z.. 93, 93, 1919.7) Glosser-Hussler: Bioch. Z., 39, 1, 1912. -8) 
Forrai: Bioch. Z., 142, 282, 1923. -9) RobinsonSoames: Biochem. J., 18, 740, 1924 - -10) RobinsonKay: Biochem. J., 18, 755, 1924. -11) Demuth: Bioch. Z., 159, 420, 1925.-12) Takahashi: Bioch. Z., 146, 161, 1924. -13) Tomita: Bioch. Z., 131 170, 1922. -14) Akamatsu: J. of Biochem., 1 , 25, 1931.-15) Schmidt: Z. f. Physiol, Chem., 208, 185, 1932. - 16) Bamann-Riedel: Z. f. Physiol. Chem., 229, 125, 1934. - 17) Waldschmidt-LeitzNonnenbruch: Naturwissenschaft, 164, 1935.-18) Dmochowski-Assenhazin: Naturwissenschaft, 501, 1935. - 19) Kutscher-Wörner: Z. f. Phys. Chem., 236, 237, 1935.-20) Kutscher-Wörner: $Z$ : f. Phys, Chem., 238, 275, 1936.--21) Kutscher-Wörner: $Z$, f. Phys. Chem., 239. 107, 1936. -22) KutscherWörner: Z. f. Phys. Chem., 235, 62, 1935. -23) Wolbergs: Z. f, Phys. Chem., 238, 23, 1936.-24) Scott-Huggins: Endocrinology, 30, 107, 1942.-25) King-Armstrong: Canad. M. A. J, 31, 376, 1934. -26) Clark: Psychosoma. Med., 12, 261, 1950.27) Clark: J. of Clinic. Endocrinology, 11, 84, 1951.-28) Horii-Akamatsu：大阪醫學會雜誌. 42, 1079, 1943.-29) Bodansky: J. of Biol, Chem., 99, 197, 1932.

\section{參考文獻}

30) Albers: Z,f.Phys. Chem., 232, 179, 1935.-31) Albers: Z. f. Phgs. Chem., 235, 47, 1935. -32) Asakawa: J. of Biochem., 10, 157, 1928. -33) Bamann-Diederich: Ber. Chem. Ges., 67, 2019, 1934.-34) Carthy-Johnston-Killian: J. Urol., 19, 43, 1928. - -35) Dettmor-Arnholdt: Dtsch. med. Wochenschr., 76, 608, 1951.一36) 出來：日本泌尿 器科學會雜誌, 41, 47, 1950.-37) Erdtmann; Z. f. Phys. Chem., 177, 211; 231, 1928.--38) Euler: Z. f. Phys. Chem., 80, 175, 1912. --39) Farrell: J.
Urol., 39, 171, 1938.-40) Forrai: Bioch. Z., 145, 54, 1924.-41) Gilbert-Margolis: J. Urol., 50, 82, 1943. -42) Gutmann; J. Clin. Inves., 17, 473, 1938. -43) Hand: J. Urol., 64, 123, 1950. -44) Herbert: Biochem. J., 38, 23, 1944.-45) Hirsch: J. Urol., 25, 669, 1931. -46) Hock-Tessier: J. Urol., 6?, 488, 1949. 一47) 堀井：大阪醫學會雜 誌, 42, 390; 903, $1943-48)$ Hudson-Butler: J. Urol., 63, 323, 1950.-49) Huggins-Clark: J. exp, Med., 72, 747, 1940.-50) Huggins-Hodges: Cancer Res., 1, 293, 1941 _ -51) Huggins-McDonald: J. Urol., 52, 472, 1944.-52) Huggins-Musima: J. exp. Med., 70, 543, 1939. - 53) Huggins-ScottHodges: J. Urol., 46, 997, 1941.-54) Ichihara: J, of Biochem., 18, 87, 1933.-55) Inoue: J. of Biochem., 7 , 433, 1929.-56) Inoue: J. of Biochem., 10, 133; 395, 1929. - 57) Iwatsuru: Bioch. Z., 173, 348, 1926. -58) Kay: Biochem. J., 20, 791, 1926.-59) Key: Biochem. J., 22, 855, 1928.-60) Kay: J. biol. Chem.. 89, 235; 249, 1930. -61) Kirk: J. of Gerontol., 3, 98, 1948.-62) Kobayashi: J. of Biochem., 8, 205, 1927.-53) Kobayashi: J. of Biochem., 10, 147, 1928. -64) Kossa: Proc. soc. exp. Biol. \& Med., 42, 23, 1939. -65) Lundquist: Nature, 16, 710, 1946.-66) Meuser-GutterHaschek: Z. f. Urol.; 44, 157, 1951. -67) Michaelis: Bioch. Z., 109, 165, 1920. -68) Munemura: J. of Biochem., 17, 343, 1933. -69) Nemec: Z. f. phys. Chem., 137, 570, 1923. - 70) Nemec: Z. f. Phys. Chem., 138, 198, 1923.-71) Neuberg: Bioch. Z., 171, 485, 1925.-72) Neuberg-Karczag: Bioch. Z., 30, 60, 1911.一73) 大越，落合：日泌 尿會誌, 42, 333, 1951.--74) Ueno: Bioch. Z., 231, 317, 1931.-..75) Wolf-Kolat-Neumann: A.J. Path., 19, 423, 1943. 